OPEN ACCESS

Edited by:

Stefania Nobili,

University of Studies G. d'Annunzio

Chieti and Pescara, Italy

Reviewed by: Alberta Bergamo, University of Trieste, Italy Giovanni Marzaro,

University of Padua, Italy

*Correspondence: Fernando R. Pavan

fernando.pavan@unesp.br

Rone A. De Grandis

r.grandis@unesp.br

Specialty section:

This article was submitted to Pharmacology of Anti-Cancer Drugs,

a section of the journal

Frontiers in Oncology

Received: 19 March 2021 Accepted: 19 May 2021

Published: 24 June 2021

Citation:

De Grandis RA, Oliveira KM, Guedes APM, dos Santos PWS, Aissa AF, Batista AA and Pavan FR (2021) A Novel Ruthenium(II) Complex With Lapachol Induces G2/M Phase

Arrest Through Aurora-B Kinase Down-Regulation and ROS-Mediated

Apoptosis in Human Prostate Adenocarcinoma Cells.

Front. Oncol. 11:682968. doi: 10.3389/fonc.2021.682968

\section{A Novel Ruthenium(II) Complex With Lapachol Induces G2/M Phase Arrest Through Aurora-B Kinase Down-Regulation and ROS-Mediated Apoptosis in Human Prostate Adenocarcinoma Cells}

\author{
Rone A. De Grandis ${ }^{1,2 *}$, Katia M. Oliveira ${ }^{3}$, Adriana P. M. Guedes ${ }^{3}$, Patrick W. S. dos Santos ${ }^{4}$, \\ Alexandre F. Aissa ${ }^{5}$, Alzir A. Batista ${ }^{3}$ and Fernando R. Pavan ${ }^{1 *}$ \\ ${ }_{1}$ School of Pharmaceutical Sciences, São Paulo State University, Araraquara, Brazil, 2 School of Medicine, University of \\ Araraquara, Araraquara, Brazil, ${ }^{3}$ Department of Chemistry, Federal University of São Carlos, São Carlos, Brazil, ${ }^{4}$ School of \\ Medicine of Ribeirão Preto, University of São Paulo, Ribeirão Preto, Brazil, ${ }^{5}$ Department of Biochemistry and Molecular \\ Genetics, University of Illinois at Chicago College of Medicine, Chicago, IL, United States
}

Lapachol is a well-studied natural product that has been receiving great interest due to its anticancer properties that target oxidative stress. In the present work, two novel lapacholcontaining ruthenium(II) complexes $[\mathrm{Ru}(\mathrm{Lap})(\mathrm{dppm})(\mathrm{bipy})] \mathrm{PF}_{6}$ (1) and $[\mathrm{Ru}(\mathrm{Lap})(\mathrm{dppm})$ (phen)]PF 6 (2) $\left[\right.$ Lap = lapachol, dppm = 1,1'-bis(diphosphino)methane, bipy $=2,2^{\prime}$ bipyridine, phen $=1,10$-phenantroline] were synthesized, fully characterized, and investigated for their cellular and molecular responses on cancer cell lines. We found that both complexes exhibited a potent cytotoxic effect in a panel of cancer cell lines in monolayer cultures, as well as in a 3D model of multicellular spheroids formed from DU145 human prostate adenocarcinoma cells. Furthermore, the complex (2) suppressed the colony formation, induced G2/M-phase arrest, and downregulated Aurora-B. The mechanism studies suggest that complex (2) stimulate the overproduction of reactive oxygen species (ROS) and triggers caspase-dependent apoptosis as a result of changes in expression of several genes related to cell proliferation and caspase- 3 and -9 activation. Interestingly, we found that $\mathrm{N}$-acetyl-L-cysteine, a ROS scavenger, suppressed the generation of intracellular ROS induced by complex (2), and decreased its cytotoxicity, indicating that ROS-mediated DNA damage leads the DU-145 cells into apoptosis. Overall, we highlighted that coordination of lapachol to phosphinic ruthenium(II) compounds considerably improves the antiproliferative activities of resulting complexes granting attractive selectivity to human prostate adenocarcinoma cells. The DNA damage 
response to ROS seems to be involved in the induction of caspase-mediated cell death that plays an important role in the complexes' cytotoxicity. Upon further investigations, this novel class of lapachol-containing ruthenium(II) complexes might indicate promising chemotherapeutic agents for prostate cancer therapy.

Keywords: lapachol, naphtoquinones, 3D-cell culture, DNA damage (comet assay), ROS - reactive oxygen species, apoptosis

\section{INTRODUCTION}

Prostate cancer is the second most frequent malignancy (after lung cancer) in the male population and rising incidences have been observed worldwide $(1,2)$. The mortality rate rises with age, and almost $55 \%$ of all deaths occur after 65 years of age (3).

The current chemotherapeutic drugs have clinically serious toxicities. Furthermore, anti-androgen drugs, designed to disrupt the function of androgens, have been linked to the onset of drug-resistant prostate cancer (4). Therefore, the development of novel chemotherapy agents remains a requirement. In the search for new anticancer drugs, several promising discoveries have been accomplished using natural products, such as naphthoquinone derivatives.

Lapachol (2-hydroxy-3-(3-methylbut-2-en-1-yl)naphthalene1,4-dione) is a naphthoquinone, which was originally isolated from species of the Bignoniaceae family (5). We, along with other research groups, have been investigating the anticancer potential of lapachol and other naphtoquinones, free or coordinated to a metal (6-10). The presence of quinone group in these molecules is responsible for their outstanding known antineoplastic characteristics, including cytotoxicity, genotoxicity, and potent antitumor properties in vivo (11).

Historically, much attention has been given to naphtoquinones after its ability to directly target DNA topoisomerases and inhibit their activity, which results in cytotoxicity (12). Recognized studies also demonstrated that lapachol can generate semiquinone radicals by bioreduction in intracellular hypoxic conditions, which is involved with the production of reactive oxygen species
(ROS) selectively in cancer cells $(13,14)$. Later, the anticancer potential of lapachol and its analogs have been extensively explored $(15,16)$. These studies reported the ability of lapachol to induce mitochondria-mediated cellular apoptosis by activating caspases and PARP (17). Lapachol analogs also downregulate the expression of the c-Myc, cyclin D1 and cyclin B1, which induce cell cycle arrest in the $S$ and $G 2 / M$ phases resulting in inhibition of tumor cell proliferation (18).

Recent studies have shown that the coordinating ability of several organic molecules toward transition metals can lead to a successful rational design of metallodrugs. In this field, rutheniumbased complexes are highlighted due to the unique properties of this metal, such as chemical stability, a variety of oxidation states, structural diversity, and low toxicity in vivo. Furthermore, ruthenium complexes under pre-clinical and clinical studies are showing promising results, representing a possible novel class of less toxic antineoplastic chemotherapy (19-21).

Hence, within the framework of our continuous effort to design novel metallodrug candidates, in the last years, our research group has synthesized several ruthenium complexes with promising pharmacological activities for the anticancer purpose (22-26). In the light of those findings, herein we have investigated for once the cellular and molecular responses of two novel lapachol-containing ruthenium(II) complexes [Ru(Lap) $(\mathrm{dppm})($ bipy) $] \mathrm{PF}_{6}(\mathbf{1})$ and $[\mathrm{Ru}(\mathrm{Lap})(\mathrm{dppm})(\mathrm{phen})] \mathrm{PF}_{6}$ (2). The corresponding complexes (Figure 1) were synthesized and characterized, and their potential as anticancer agents was investigated on human prostate adenocarcinoma cells.
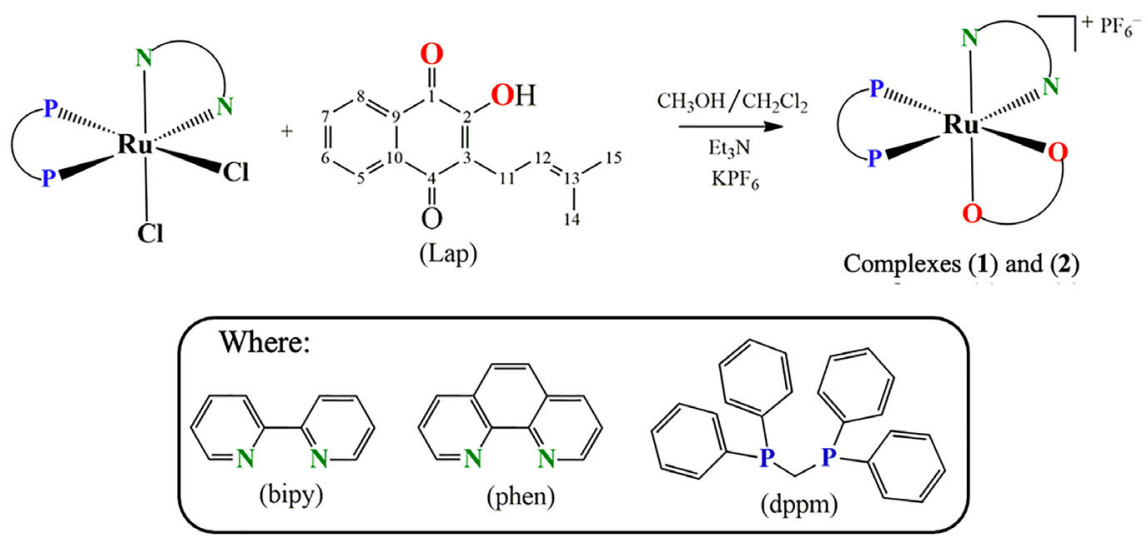

FIGURE 1 | Route for the synthesis of complexes $[R u(L a p)(d p p m)(b i p y)] P F_{6}$ (1) and $[R u(L a p)(d p p m)(p h e n)] P F_{6}$ (2) 


\section{MATERIAL AND METHODS}

\section{Synthesis and Characterization of Novel Lapachol-Containing Ruthenium Complexes}

All procedures involving solutions of the complexes were performed under inert argon atmosphere, and all reagents used were of analytical or pure grade, and the solvents were dried using appropriate agents. The $\mathrm{RuCl}_{3} \cdot \mathrm{nH}_{2} \mathrm{O}$, bis(diphenylphosphine) methane (dppm), 2,2'-bipyridine (bipy), 1,10-phenanthroline (phen), and $\mathrm{KPF}_{6}$ were purchased from Sigma-Aldrich MERCK (St. Louis, MO, USA) and used as received. Lapachol (Lap) was extracted from the bark of Tabebuia aurea (Manso) S. Moore as reported in the literature (27).

The ${ }^{1} \mathrm{H},{ }^{13} \mathrm{C}\left\{{ }^{1} \mathrm{H}\right\}$ and ${ }^{31} \mathrm{P}\left\{{ }^{1} \mathrm{H}\right\}$ NMR experiments were recorded on a $9.4 \mathrm{~T}$ Bruker Avance III $400 \mathrm{MHz}$ spectrometer using a $5-\mathrm{mm}$ internal diameter indirect probe with Automatic Tuning Matching. Electrochemical assays were executed using a Bioanalytical Systems Inc, model BAS-100B/W at room temperature in $\mathrm{CH}_{2} \mathrm{Cl}_{2}$ containing $0.10 \mathrm{M} \mathrm{Bu}_{4} \mathrm{NClO}_{4}$ (TBAP) (Fluka Purum) as a support electrolyte. The $\mathrm{Ag} / \mathrm{AgCl}(0.10 \mathrm{M}$ $\mathrm{Bu}_{4} \mathrm{NOH}$ in $\mathrm{CH}_{2} \mathrm{Cl}_{2}$ ) in a Luggin capillary probe was used as reference electrode and platinum foils as working and auxiliary electrodes. The IR spectra were acquired using a FT-IR BomemMichelson 102 spectrometer using $\mathrm{KBr}$ pellets. Elemental analysis $(\mathrm{C}, \mathrm{H}$, and $\mathrm{N})$ was determined using an CHNS Element Analyzer (Thermo Fischer Scientific, Fisons EA-1108 model). UV-vis spectra were recorded in a Hewlett Packard diode array-8452A spectrophotometer. Conductivity was acquired using a MeterLab CDM2300 at room temperature.

The precursors complexes with general formula cis- $\left[\mathrm{RuCl}_{2}\right.$ $(\mathrm{dppm})(\mathrm{N}-\mathrm{N})]$, where $\mathrm{N}-\mathrm{N}=2,2^{\prime}$-bipyridine (bipy) or 1,10 phenanthroline (phen) and dppm $=b i s$ (diphenylphosphine) methane, were synthesized according to described in the literature $(23,28,29)$.

\section{[Ru(Lap)(dppm)(bipy)]PF 6 (1)}

To a Schlenk flask containing $40 \mathrm{ml}$ of dichlorometane and $40 \mathrm{ml}$ of acetone $(1: 1, \mathrm{v} / \mathrm{v})$, the cis- $\left[\mathrm{RuCl}_{2}(\mathrm{dppm})(\mathrm{bipy})\right](0.14 \mathrm{mmol})$, lapachol $(0.21 \mathrm{mmol}), \mathrm{KPF}_{6}(0.28 \mathrm{mmol})$, and $50 \mu \mathrm{l}$ of triethylamine were added. The reaction was maintained in reflux under argon atmosphere for $12 \mathrm{~h}$. After that, the volume of the mixture was reduced to ca. $3 \mathrm{ml}$, and the complex precipitated by addition of $1 \mathrm{ml}$ of water. The solid was filtered off, washed with water, diethyl ether and dried under vacuum. Yield: $0.109 \mathrm{~g}(76 \%)$. Elemental analysis for $\left[\mathrm{C}_{50} \mathrm{H}_{43} \mathrm{~F}_{6} \mathrm{~N}_{2} \mathrm{O}_{3} \mathrm{P}_{3} \mathrm{Ru}\right]$ : exp. (calc): $\mathrm{C}, 58.85$ (58.43), $\mathrm{H}, 4.40$ (4.22), and $\mathrm{N}, 2.85$ (2.73). $\Lambda_{\mathrm{M}}=59 \Omega^{-1} \mathrm{~cm}^{2} \mathrm{~mol}^{-1}$, in $1.0 \mathrm{mM} \mathrm{CH}_{2} \mathrm{Cl}_{2}$ solution. IR $\left(\mathrm{cm}^{-1}\right): v\left(\mathrm{C}_{1}=\mathrm{O}\right) 1546, v\left(\mathrm{C}_{4}=\mathrm{O}\right)$ $1608, v\left(\mathrm{C}_{2}-\mathrm{O}\right) 1103, v(\mathrm{P}-\mathrm{F}) 840$ and $557, v(\mathrm{Ru}-\mathrm{O}) 510$ and $v(\mathrm{Ru}-$ N) 483. ${ }^{31} \mathrm{P}\left\{{ }^{1} \mathrm{H}\right\} \mathrm{NMR}\left(162 \mathrm{MHz}, \mathrm{CH}_{2} \mathrm{Cl}_{2}, 298 \mathrm{~K}\right): \delta$ (ppm) 18.2; $6.2 / 14.7 ; 5.8 /^{2} \mathrm{~J}=76.1 / 66.4,-144\left(1 \mathrm{P}\right.$, hept, $\left.P F_{6}^{-}, J_{\mathrm{PF}}=711 \mathrm{~Hz}\right)$. ${ }^{1} \mathrm{H} \mathrm{NMR}\left(400 \mathrm{MHz}, \mathrm{DMSO}_{6}\right.$, $\left.298 \mathrm{~K}\right): \delta$ (ppm) 8.7-6.6 (m, 32H, an overlap of aromatic protons of dppm (20 H), bipy (8H), and Lap (4H)), 5.4 (m, 1H, Lap), 4.8 (m, 2H, dppm), 3.1-2.8 (m, 2H, Lap), $1.4-1.3\left(\mathrm{~m}, 6 \mathrm{H}, 2 \mathrm{CH}_{3}\right.$ of Lap). ${ }^{13} \mathrm{C}\left\{{ }^{1} \mathrm{H}\right\}$ NMR $(125.74 \mathrm{MHz}$, DMSO$\left.\mathrm{d}_{6}, 298 \mathrm{~K}\right): \delta(\mathrm{ppm}) 196.5\left(\mathrm{C}_{1}=\mathrm{O}\right), 181.4\left(\mathrm{C}_{4}=\mathrm{O}\right), 169.6\left(\mathrm{C}_{2}-\mathrm{O}\right)$.

\section{[Ru(Lap)(dppm)(phen)]PF 6 (2)}

To a Schlenk flask containing $40 \mathrm{ml}$ of dichlorometane and $40 \mathrm{ml}$ of acetone $(1: 1, \mathrm{v} / \mathrm{v})$, the $c i s-\left[\mathrm{RuCl}_{2}(\mathrm{dppm})(\mathrm{phen})\right](0.17 \mathrm{mmol})$, lapachol $(0.21 \mathrm{mmol}), \mathrm{KPF}_{6}(0.28 \mathrm{mmol})$, and $50 \mu \mathrm{l}$ of triethylamine were added. For the synthesis of this complex, the same procedure of complex (1) was used. Yield: $0.107 \mathrm{~g}$ (75\%). Elemental analysis for $\left[\mathrm{C}_{52} \mathrm{H}_{43} \mathrm{~F}_{6} \mathrm{~N}_{2} \mathrm{O}_{3} \mathrm{P}_{3} \mathrm{Ru}\right]$ : exp. (calc): C, 59.71 (59.37); $\mathrm{H}, 4.39$ (4.12); and N, 2.95 (2.66). $\Lambda_{\mathrm{M}}=38.27$ $\Omega^{-1} \mathrm{~cm}^{2} \mathrm{~mol}^{-1}$, in $1.0 \mathrm{mM} \mathrm{CH}_{2} \mathrm{Cl}_{2}$ solution. IR $\left(\mathrm{cm}^{-1}\right): v\left(\mathrm{C}_{1}=\mathrm{O}\right)$ $1547, v\left(\mathrm{C}_{4}=\mathrm{O}\right) 1610, v\left(\mathrm{C}_{2}-\mathrm{O}\right) 1097, v(\mathrm{P}-\mathrm{F}) 837$, and 555, $v(\mathrm{Ru}-$ O) 508 and $v(\mathrm{Ru}-\mathrm{N}) 480 .{ }^{31} \mathrm{P}\left\{{ }^{1} \mathrm{H}\right\} \mathrm{NMR}\left(162 \mathrm{MHz}, \mathrm{CH}_{2} \mathrm{Cl}_{2}\right.$, $298 \mathrm{~K}): \delta(\mathrm{ppm}) 18.3 ; 7.1 / 14.9 ; 6.5 /^{2} \mathrm{~J}=74.5 / 68.0,-144(1 \mathrm{P}, \mathrm{hept}$, $\left.P F_{6}^{-}, J_{\mathrm{PF}}=711 \mathrm{~Hz}\right) .{ }^{1} \mathrm{H}$ NMR $\left(400 \mathrm{MHz}, \mathrm{DMSO}-\mathrm{d}_{6}, 298 \mathrm{~K}\right): \delta$ (ppm) 9.0-6.3 (m, 32H, an overlap of aromatic protons of dppm $(20 \mathrm{H})$, phen $(8 \mathrm{H})$, and Lap $(4 \mathrm{H})), 5.5(\mathrm{~m}, 1 \mathrm{H}$, Lap), $4.8(\mathrm{~m}, 2 \mathrm{H}$, dppm), 3.2-2.8 (m, 2H, Lap), 1.8-1.7 (m, 6H, 2 $\mathrm{CH}_{3}$ of Lap). ${ }^{13} \mathrm{C}$ $\left\{{ }^{1} \mathrm{H}\right\}$ NMR $\left(125.74 \mathrm{MHz}, \mathrm{DMSO}-\mathrm{d}_{6}, 298 \mathrm{~K}\right): \delta(\mathrm{ppm}) 196.8$ $\left(\mathrm{C}_{1}=\mathrm{O}\right), 181.8\left(\mathrm{C}_{4}=\mathrm{O}\right), 169.6\left(\mathrm{C}_{2}-\mathrm{O}\right)$.

\section{Partition Coefficient (n-Octanol/Water) Determination}

The octanol-water partition coefficients $(\log P)$ were quantified using the shake-flask method (30). Each complex was tested in a mixture of equal volumes of water and $n$-octanol with continuous shaking for $24 \mathrm{~h}$ at $112 \mathrm{~g}$ and $37^{\circ} \mathrm{C}$. Then the samples were centrifuged for $5 \mathrm{~min}$ at $10 \mathrm{~g}$, and the organic and aqueous phases were separated. The concentration of complex in each phase was measured spectrophotometrically to determine values of $\log P=$ [compound] (in $n$-octanol)/ [compound] (in water). The experiments were carried out in triplicate.

\section{Cell Lines and Culture Conditions}

Human lung carcinoma (A549, ATCC $^{\circledR}$ CCL-185 ${ }^{\mathrm{TM}}$ ), human hepatocellular carcinoma (HepG2, ATCC ${ }^{\circledR}$ HB-8065 ${ }^{\mathrm{TM}}$ ), and human breast adenocarcinoma (MDA-MB-231, ATCC ${ }^{\circledR}$ HTB$26^{\mathrm{TM}}$ ) were obtained from American Type Cell Collection (ATCC). Human melanoma (A-375, BCRJ-0278), Human colorectal adenocarcinoma (Caco-2, BCRJ 0059), human prostate adenocarcinoma (DU-145, BCRJ-0078, and PC-3, BCRJ-0269), human mouth fibroblast (FGH, BCRJ-0089), and human prostate epithelial cells (PNT-2, BCRJ-0366) were obtained from Rio de Janeiro Cells Bank (BCRJ). The cells A549, A-375, Caco-2, DU-145, HepG2, MDA-MB-231, and FGH were cultured in Dulbecco's Modified Eagle's Medium (DMEM, Gibco-Invitrogen ${ }^{\circledR}$ ), PC-3 and PNT-2 cells were grown in Roswell Park Memorial Institute Medium (RPMI1640 , Gibco-Invitrogen $\left.{ }^{\circledR}\right)$. Both mediums were supplemented according to the needs of each lineage, as recommended by its cell banks with $2 \mathrm{mM}$ L-glutamine (Gibco-Invitrogen ${ }^{\circledR}$ ), $10 \%$ or $20 \%$ fetal bovine serum (Gibco-Invitrogen ${ }^{\circledR}$ ), $1 \%$ antibioticantimycotic solution $(5 \mathrm{mg} / \mathrm{ml}$ penicillin, $5 \mathrm{mg} / \mathrm{ml}$ streptomycin, and $10 \mathrm{mg} / \mathrm{ml}$ neomycin, Gibco-Invitrogen ${ }^{\circledR}$ ), and $3.7 \mathrm{~g} / \mathrm{L}$ of $\mathrm{NaHCO}_{3}$ (Sigma-Aldrich). All cell lines were cultured in flasks at $37^{\circ} \mathrm{C}$ in $5 \% \mathrm{CO}_{2}$ and $96 \%$ of relative humidity according to the procedures proposed by (31), and a 
mycoplasma stain kit (Sigma-Aldrich) was used to confirm the use of cells devoid of contamination. The assays were conducted between the third and the seventh-cell passage with sub-cultures every 3 to 4 days to maintain exponential growth. The cell viability was checked using the trypan blue dye exclusion assay for all experiments where over $95 \%$ of the cells were viable at the beginning of the tests.

\section{Cytotoxicity Activity Assay}

The in vitro antiproliferative activity was quantified using the Alamar blue ${ }^{\circledR}$ assay, according to the method reported by (32). Cells were seeded in 96-well plates for all experiments $\left(1.5 \times 10^{4}\right.$ cells/well). After $24 \mathrm{~h}$, the complexes were dissolved in DMSO and added to each well and incubated for $24 \mathrm{~h}$. Dilutions of the complexes were prepared to obtain concentrations ranging from 0.3 to $100 \mu \mathrm{M}$. Cisplatin (Fauldcispla ${ }^{\circledR}$ ) and doxorubicin hydrochloride (Fauldoxo ${ }^{\circledR}$ ) were used as the reference cytotoxic drugs. DMSO $(0.1 \% \mathrm{v} / \mathrm{v})$ was used as the vehicle control. Following $24 \mathrm{~h}$ of incubation, $50 \mu \mathrm{l}$ of Alamar blue ${ }^{\circledR}$ (resazurin at $0.01 \% \mathrm{w} / \mathrm{v}$, Sigma-Aldrich) was added to each well, and the plates were incubated, at $37^{\circ} \mathrm{C}$, in the dark. Fluorescence reading was performed in a Synergy $\mathrm{H} 1$ Fluorescence Spectrophotometer $\left(\right.$ BioTek $^{\circledR}$ ), using excitation and emission filters at wavelengths of 560 and $590 \mathrm{~nm}$, respectively. The fluorescence intensity was measured in arbitrary fluorescence units (AFU) and the AFU of untreated cells (CTL) was considered $100 \%$. The cytotoxic effects of the compounds were estimated in terms of cell proliferation inhibition (\%) and expressed as half-maximal inhibitory concentration $\left(\mathrm{IC}_{50}\right)$. The cell proliferation inhibition percentage of cells exposed to treatments was calculated following: $\%$ Inhibition $=100-$ $($ AFU of treated well/AFU of control well $) \times 100$ ). The $\mathrm{IC}_{50}$ values were calculated from the cell proliferation inhibition percentage by nonlinear regression method using CompusSyn ${ }^{\circledR}$ Software.

\section{D Multicellular Tumor Spheroids Culture}

Multicellular tumor spheroids (MCTSs) were obtained according to the method reported by (33). Briefly, $200 \mu \mathrm{l}$ of a solution of DU-145 cells $\left(2.0 \times 10^{3}\right.$ cells/well $)$ were inserted in agarosecoated 96-well plates $(1.5 \% \mathrm{w} / \mathrm{v})$ and cultured in complete medium plus 3\% Matrigel $^{\circledR}$ (Corning). DU-145-MCTSs with stable structures had formed after five days. Then, spheroids were exposed to the complexes in a range of five different concentrations varying from 0.25 to $4.0 \mu \mathrm{M}$ and incubated for $24 \mathrm{~h}$. Cisplatin (Fauldcispla ${ }^{\circledR}$ ) at $25 \mu \mathrm{M}$ was used as the reference cytotoxic drug. Negative control received the vehicle (DMSO $0.1 \% \mathrm{v} / \mathrm{v}$ ) that was used for diluting the compounds tested. Finally, the MCTS proliferation inhibition (\%) and $\mathrm{IC}_{50}$ were determined by Alamar blue ${ }^{\circledR}$ assay as described above. To investigate morphological changes other MCTSs were treated with $0.25,0.5,1.0,1.5$, and $2.0 \mu \mathrm{M}$ of complex (2) and examined for 7 days. Spheroid integrity and diameter of MCTSs were analyzed by phase-contrast microscopy (Inverted Trinocular Microscope Opton TNB-O5T-PL) using AxioVision LE software (Carl Zeiss, Germany).

\section{Clonogenic Assay}

The clonogenic assay was performed in accordance with the guidelines of (34). The DU-145 cells $\left(1 \times 10^{6}\right.$ cells/well $)$ were inserted in six-well plate and treated with different concentrations varying of 0.125 to $1.5 \mu \mathrm{M}$ of both complexes. Cisplatin (Fauldcispla ${ }^{\circledR}$ ) and doxorubicin hydrochloride (Fauldoxo ${ }^{\circledR}$ ) were used as the reference cytotoxic drugs. DMSO $(0.1 \% \mathrm{v} / \mathrm{v})$ was used as the vehicle control. After $24 \mathrm{~h}$, the cells were washed with PBS (Gibco-Invitrogen ${ }^{\circledR}$ ) and harvested by trypsinization. Cells were counted using a Neubauer chamber and replated then on cell culture dishes of $21.5 \mathrm{~cm}^{2}$ in a density of 200 cells per culture dish for each treatment in triplicate. After 7 days, cells were fixed in ice-cold methanol: acetic acid: distilled water (1:1:8), air-dried, and stained with crystal violet $(0.5 \% \mathrm{w} / \mathrm{v}$, Sigma-Aldrich) for $20 \mathrm{~min}$. Colonies with at least 50 cells were counted. Plating efficiency (PE) of DU-145 cells was calculated by the ratio of the number of colonies observed after 7 days of incubation to the number of cells seeded (two hundred). The average of colonies in control was considered as $100 \%$, and the number of colonies that arise after treatment of cells is called the surviving fraction (SF), obtained by:

$$
S F=\frac{\text { Number of colonies counted in each treatment }}{\text { Number of colonies counted in control } \times P E} \times 100
$$

\section{Cell Cycle Analysis}

DNA staining was performed using BD Cycletest ${ }^{\mathrm{TM}}$ Plus DNA Kit (BD Biosciences, USA) according to the manufacturer's instructions. Briefly, DU-145 cells were seeded $\left(5.0 \times 10^{4}\right.$ cells/ well) into 24 -well culture plates and maintained to attach at $37^{\circ} \mathrm{C}$ in $5 \% \mathrm{CO}_{2}$. After $24 \mathrm{~h}$, the culture medium was replaced by complete culture medium containing $0.25,0.5,1.0$, and $1.5 \mu \mathrm{M}$ of complex (2). DMSO (0.1\% v/v) was used as the vehicle control. Then, after $24 \mathrm{~h}$ treatment, the cells were harvested and fixed with $70 \%$ ethanol at $4^{\circ} \mathrm{C}$ for $1 \mathrm{~h}$. Cells were incubated with $0.1 \mathrm{mg} / \mathrm{ml}$ RNase and $0.5 \mathrm{mg} / \mathrm{ml}$ propidium iodide (PI) for $10 \mathrm{~min}$. Samples were then filtered using $50-\mu \mathrm{m}$ nylon mesh and the FACSCanto flow cytometer (Becton Dickinson, Franklin Lakes, NJ, USA) was used to analyze the DNA histogram. Data from 10,000 cells were acquired and analyzed using the ModFit software (BD Biosciences, USA). The results were expressed as percentage of cells in each cell cycle phase (G1, S, and G2/M).

\section{Annexin-V/PI Staining Assay}

The measurement of cell death was performed by the guidelines of (35). Detection of apoptotic/necrotic cells was determined by flow cytometry using the Alexa Fluor ${ }^{\circledR} 488$ Annexin V/PI (Thermo Fischer Scientific), and the analyses were performed according to the manufacturer's instructions. Briefly, DU-145 cells were seeded $\left(5.0 \times 10^{4}\right.$ cells/well $)$ in 12-well plates and maintained to attach at $37^{\circ} \mathrm{C}$ in $5 \% \mathrm{CO}_{2}$ for $24 \mathrm{~h}$. After, cells were treated with $0.25,0.5,1.0$, and $1.5 \mu \mathrm{M}$ of both complexes. Cisplatin (Fauldcispla ${ }^{\circledR}$ ) and doxorubicin hydrochloride (Fauldoxo ${ }^{\circledR}$ ) were used as the reference cytotoxic drugs. 
DMSO $(0.1 \% \mathrm{v} / \mathrm{v})$ was used as the vehicle control. Following $24 \mathrm{~h}$ of incubation, the cells were collected with Accutase ${ }^{\circledR}$ (GibcoInvitrogen ${ }^{\circledR}$ ), washed with PBS and resuspended in $200 \mu \mathrm{l}$ of cold annexin-binding buffer. Next, $10 \mu \mathrm{l}$ of Alexa Fluor ${ }^{\circledR}$ was added to Annexin V (50 $\mu \mathrm{l} / \mathrm{ml})$ staining buffer, and the mixture was incubated in the dark at $4^{\circ} \mathrm{C}$ for $15 \mathrm{~min}$. Previously, the analyses, $100 \mu \mathrm{l}$ of PI $(2 \mu \mathrm{g} / \mathrm{ml})$ was added, and then, the fluorescence was measured by flow cytometry in a FACSCanto flow cytometer (BD Biosciences, USA) using the Diva software. Ten thousand events were evaluated per experiment, and cellular debris was omitted from the analysis.

\section{Measurement of Cellular Reactive Oxygen Species Levels}

Total intracellular ROS generation was measured using $2^{\prime}, 7^{\prime}$ dichlorodihydrofluorescein diacetate $\left(\mathrm{H}_{2} \mathrm{DCFDA}\right.$, Sigma-Aldrich), as reported by (36). Briefly, DU-145 cells were seeded $\left(1.5 \times 10^{4}\right.$ cells/well) into black 96-well plates and maintained to attach at $37^{\circ} \mathrm{C}$ in $5 \% \mathrm{CO}_{2}$. After $24 \mathrm{~h}$, cells were treated with $1.0 \mu \mathrm{M}\left(\sim \mathrm{IC}_{50}\right)$ of the complex (2) for 1, 6, 12, and 24h. After that, cells were labeled with $\mathrm{H}_{2}$ DCFDA solution at $5 \mu \mathrm{M}$ in N,N-dimethylformamide (SigmaAldrich). After that, fluorescence intensity was measured in a Synergy H1 Fluorescence Spectrophotometer (BioTek ${ }^{\circledR}$ ), at the excitation and emission wavelengths of 495 and $527 \mathrm{~nm}$, respectively. Thereafter, ROS/Superoxide levels were measured using Cellular ROS/Superoxide Detection Assay Kit $\left(\mathrm{Abcam}^{\circledR}\right)$. Cells were seeded $\left(1.5 \times 10^{4}\right.$ cells/well $)$ into black 96-well plates and maintained to attach at $37^{\circ} \mathrm{C}$ in $5 \% \mathrm{CO}_{2}$. After $24 \mathrm{~h}$, cells were treated with complex (2) $(0.25,0.50,1.0$, and $1.5 \mu \mathrm{M})$ for $24 \mathrm{~h}$. Negative control received the vehicle (DMSO $0.1 \% \mathrm{v} / \mathrm{v}$ ), and positive control received pyocyanin $(250 \mu \mathrm{M})$ as ROS inducer. Following this, cells were labeled with oxidative stress detection reagent (Green) for ROS detection and superoxide detection reagent (Orange) according to the manufacturer's instruction. Fluorescence was measured in quadruplicates using a fluorescent microplate reader Synergy H1 $\left(\right.$ BioTek $\left.^{\circledR}\right)$ with standard fluorescein $(\mathrm{Ex}=488$ $\mathrm{nm}, \mathrm{Em}=520 \mathrm{~nm})$ and rhodamine $(\mathrm{Ex}=550 \mathrm{~nm}, \mathrm{Em}=610 \mathrm{~nm})$ filter sets for ROS and superoxide determination, respectively. Protection assays using the antioxidant $N$-acetyl-L-cysteine (NAC) were also performed. In brief, the cells were treated with $5 \mathrm{mM} \mathrm{NAC}$ (Sigma-Aldrich) in association with complex (2) (0.50, 1.0, and 1.5 $\mu \mathrm{M})$ for $24 \mathrm{~h}$. Cells were labeled as described above, and the ROS levels were measured. In a new set of experiments, cells were treated with $5 \mathrm{mMNAC}$ in association with cytotoxic concentrations of (2). After $24 \mathrm{~h}$ of treatment, the cell viability was determined by Alamar blue $^{\circledR}$ assay as described above.

\section{Assessment of DNA Damage by Comet Assay}

The comet assay was performed to evaluate DNA damage following the method described by (37). Briefly, DU-145 and PNT-2 cells were seeded $\left(1.0 \times 10^{5}\right.$ cells/well $)$ in 24 -well plates and maintained to attach at $37^{\circ} \mathrm{C}$ in $5 \% \mathrm{CO}_{2}$ for $24 \mathrm{~h}$. After, cells were treated with different concentrations of complex (2) for $24 \mathrm{~h}$. DMSO $(0.1 \% \mathrm{v} / \mathrm{v})$ was used as the vehicle control and methyl methanesulfonate $(150 \mu \mathrm{M}$, Sigma-Aldrich) as DNA damage inducer. Following $24 \mathrm{~h}$ of incubation, the cells were collected, and cell viability assay was performed using trypan blue dye. Analyzed samples showed more than $70 \%$ of viability (data not shown). Then, cells were mixed with UltraPure ${ }^{\mathrm{TM}}$ LowMelting-Point Agarose (0.5\%, Invitrogen $\left.{ }^{\circledR}\right)$, and added on precoated slides with UltraPure ${ }^{\mathrm{TM}}$ Agarose (1.5\%, Invitrogen $\left.{ }^{\circledR}\right)$. After agarose solidification, the slides were immersed in a lysis solution (2.5 M NaCl, $100 \mathrm{mM}$ EDTA, $10 \mathrm{mM}$ Tris, 10\% DMSO, $1 \%$ Triton $\mathrm{X}-100, \mathrm{pH} 10.4)$ for $18 \mathrm{~h}$ at $4^{\circ} \mathrm{C}$. After that, the slides were added with electrophoresis buffer $(300 \mathrm{mM} \mathrm{NaOH}, 1 \mathrm{mM}$ EDTA, $\mathrm{pH}>13.4$ ) to the electrophoresis chamber. The electrophoresis run was set up for $20 \mathrm{~min}$ of an electric field of $25 \mathrm{~V}$ and $300 \mathrm{~mA}(0.9 \mathrm{~V} / \mathrm{cm})$. Slides were neutralized (0.4 M Tris, $\mathrm{pH} 7.5,4^{\circ} \mathrm{C}$ ) and fixed in absolute ethanol for $5 \mathrm{~min}$. Dried slides were stained with Gel $\operatorname{Red}^{\circledR}\left(1: 10,000\right.$, Uniscience $\left.{ }^{\circledR}\right)$. The nucleoids were identified in a fluorescence microscope (AxioStar Plus, Carl Zeiss Axio Cam MRc-AxioVision 3.1) using a 516 to $560 \mathrm{~nm}$ filter, $590 \mathrm{~nm}$ filter barrier, in $20 \times$ objective with an integrated digital camera. For each treatment, 100 random nucleoids were analyzed, and the tail fluorescence was measured through the Comet Assay $\mathrm{IV}^{\mathrm{TM}}$ imaging system (Perceptive Instruments ${ }^{\odot}$, Bury St Edmunds, England).

\section{DNA Interactions Assay With pBR322 Plasmid}

Plasmid pBR322 (38 $\mu \mathrm{M}$, Sigma-Aldrich) was mixed with different concentrations $(0.125-1.0 \mu \mathrm{M})$ of both complexes and incubated at $37^{\circ} \mathrm{C}$ for $18 \mathrm{~h}$. Then, the loading buffer was added and the samples were analyzed by agarose gel electrophoresis for $90 \mathrm{~min}$ in $1 \%$ agarose gel using a Tris-acetate-EDTA (TAE) buffer (0.45 M Tris- $\mathrm{HCl}, 0.45 \mathrm{M}$ acetic acid, $10 \mathrm{mM}$ EDTA, $\mathrm{pH}$ 7.4), and ethidium bromide was employed for staining. Bands were visualized with a ChemiDoc MP imager (BioRad, USA).

\section{DNA Minor Groove Interaction Assay With Hoechst 33258}

DNA minor groove interaction was assessed by examining the ability of the complexes to displace Hoechst 33258 (Thermo Fischer Scientific) from calf thymus DNA (ct-DNA) (SigmaAldrich). The ct-DNA solution was prepared by dilution of $2 \mathrm{mg}$ of the ct-DNA in $1 \mathrm{ml}$ of Tris- $\mathrm{HCl}$ buffer $(4.5 \mathrm{mM}$ Tris- $\mathrm{HCl}, 0.5$ $\mathrm{mM}$ Tris-base, $50 \mathrm{mM} \mathrm{NaCl}, \mathrm{pH} 7.4$ ), and the concentration was determined by absorption spectrophotometric using the molar absorption coefficient $6600 \mathrm{~mol}^{-1} \mathrm{dm}^{3} \mathrm{~cm}^{-1}$ at $260 \mathrm{~nm}$ (38). Thus, the ct-DNA $(125 \mu \mathrm{M})$ was incubated with Hoechst $(2.7$ $\mu \mathrm{M})$, and the extinction of the fluorescence intensity was monitored by the addition of different concentrations (0-125 $\mu \mathrm{M}$ ) of both complexes in Tris- $\mathrm{HCl}$ containing $10 \%$ of DMSO. Fluorescence emission spectra were recorded from 300 to 500 $\mathrm{nm}$ after excitation wavelength of $343 \mathrm{~nm}$, using an opaque 96well plate, in a Synergy H1 Fluorescence Spectrophotometer $\left(\right.$ BioTek $^{\circledR}$ ), at $37^{\circ} \mathrm{C}$.

\section{Gene Expression Analysis by qPCR Array}

Briefly, DU-145 cells were seeded $\left(1.0 \times 10^{6}\right.$ cells/well $)$ into sixwell plates and maintained to attach at $37^{\circ} \mathrm{C}$ in $5 \% \mathrm{CO}_{2}$. After 
$24 \mathrm{~h}$, the cells were treated with $1.0 \mu \mathrm{M}$ of the complex (2). DMSO $(0.1 \% \mathrm{v} / \mathrm{v})$ was used as the vehicle control. After $12 \mathrm{~h}$ of incubation, total RNA was isolated from the cells using the RNeasy ${ }^{\circledR}$ Mini kit (Qiagen, Germany) according to the manufacturer's instructions. RNA was quantified by NanoDrop spectrophotometer (ND-2000; Thermo Fischer Scientific). The Agilent 2100 Bioanalyzer and Agilent RNA 6000 Nanochip kits were used to assess the total RNA quality as per manual instruction (Agilent, USA). The Agilent 2100 Expert software (Version B.02.07.SI532) was used with the Eukaryote Total RNA Nano assay on the Agilent 2100 bioanalyzer. No significant differences in RIN values were observed across the samples. Complementary DNA strands were synthesized using the $\mathrm{RT}^{2}$ First Strand kit (Qiagen, Germany), following the manufacturer's instructions. Gene expression profiling was performed using the $\mathrm{RT}^{2}$ Profiler ${ }^{\mathrm{TM}}$ PCR Array Human Cancer Drug Targets (PAHS 507Z, Qiagen) by qPCR. The reactions were conducted in the Applied Biosystems 7500 PCR System (Applied Biosystems, USA) thermocycler. The plate was heated to $95^{\circ} \mathrm{C}$ for $10 \mathrm{~min}$, followed by 40 cycles of $95^{\circ} \mathrm{C}$ for $15 \mathrm{~s}$ and $60^{\circ} \mathrm{C}$ for $1 \mathrm{~min}$, followed by the dissociation curve. The expression profile of 84 key drug targets genes was analyzed. Fold changes amplification for targeted genes was normalized to the housekeeping genes GAPDH and RPLPO by the delta-delta cycle threshold method $(\Delta \Delta \mathrm{Ct})$, and the cells treated with vehicle control $(0.1 \%$ of DMSO v/v) was used as calibrator. The threshold cycle values of control wells were all within the ranges recommended by the PCR array user manual. Three independent biological replicates were performed. All experiments were performed in DNase/RNase free conditions. Genes were considered differentially regulated if the difference was $\geq 1.8$-fold, which means that the gene expression in the compound-treated cells was at 1.8 -fold that in the negative control-treated cells. Differences were considered significant at $p \leq 0.05$. Statistical analysis of two groups was performed automatically according to the GeneGlobe Data Analysis Center (Qiagen, USA; https://geneglobe.qiagen.com/us/analyze).

\section{Protein Extraction and Western Blot}

Briefly, DU- 145 cells were seeded $\left(1.0 \times 10^{6}\right.$ cells/well $)$ into sixwell plates and maintained to attach at $37^{\circ} \mathrm{C}$ in $5 \% \mathrm{CO}_{2}$. After $24 \mathrm{~h}$, cells were treated with $0.25,0.50,1.0$, and $1.5 \mu \mathrm{M}$ of complex (2). DMSO $(0.1 \% \mathrm{v} / \mathrm{v})$ was used as the vehicle control. After $24 \mathrm{~h}$ of incubation, cells were collected and suspended in Western blotting lysis buffer (20 mM Tris- $\mathrm{HCl}$ pH 7.4, $150 \mathrm{mM}$ $\mathrm{NaCl}, 1 \mathrm{mM}$ EDTA, and phosphatase and protease inhibitors). Cell lysates were centrifuged at $11,000 \mathrm{~g}$ for $15 \mathrm{~min}$ at $4{ }^{\circ} \mathrm{C}$, and supernatant was collected. Protein concentrations were quantified using the BCA Protein Assay Kit ${ }^{\circledR}$ (Thermo Fischer Scientific), according to the manufacturer's instructions. For immunoblotting, equal amounts $(30 \mu \mathrm{g})$ of total protein were electrophoresed in a NuPAGE ${ }^{\circledR} 4-12 \%$ Bis-Tris gel and transferred to an Invitrolon ${ }^{\mathrm{TM}}$ polyvinylidene difluoride (PVDF) membrane $\left(\right.$ Novex $^{\circledR}$, Thermo Fischer Scientific) at $100 \mathrm{~V}$ for $1 \mathrm{~h}$. PVDF-membrane was washed two times (5 min each) with Tris-buffered saline plus Tween 20 (TBST, SigmaAldrich) and blocked in 5\% non-fat milk in phosphate buffered saline with Tween ${ }^{\circledR} 20$ (PBST, Sigma-Aldrich) for $1 \mathrm{~h}$ at room temperature. After, the membranes were incubated $4 \mathrm{~h}$ at $18^{\circ} \mathrm{C}$ with primary antibodies against $\beta$-actin (ab8226, Abcam, 1:1000), PARP1 (ab74290, Abcam, 1:1000), cleaved PARP1 (ab32064, Abcam, 1:1000), cleaved caspase-3 (ab2302, Abcam, 1:1000), cleaved caspase-8 (MA5-15054, Thermo Fischer Scientific, 1:500), cleaved caspase-9 (ab2324, Abcam, 1:1000), and aurora B (ab2254, Abcam, 1:1000), previously diluted in blocking solution to appropriate concentrations. After removing unbound primary antibodies, membranes were washed four times (7.5 min each) with TBST buffer (100 mM Tris- $\mathrm{HCl}$, $300 \mathrm{mM} \mathrm{NaCl}, 1 \%$ Tween 20) and incubated with the respective secondary goat anti-mouse HRP antibody (1:3000 diluted in 1\% non-fat milk in TBST; NA931V, GE Healthcare) for $1 \mathrm{~h}$ at room temperature. Membranes were washed additional eight times (7.5 min. each) with TBST before performing the enhanced chemiluminescence step using ChemiDoc ${ }^{\mathrm{TM}}$ MP Image System (Bio-Rad, USA). Digital images were acquired using a software Scion Imaging (Scion Corporation, USA). The protein $\beta$-actin was used for sample loading normalization.

\section{Statistical Analysis}

Data are presented as mean \pm S.E.M. or as $\mathrm{IC}_{50}$ values with $95 \%$ confidence intervals (CI 95\%) obtained by nonlinear regression. Differences between experimental groups were compared using analysis of variance (ANOVA) followed by the Dunnet's or Tukey's test $(p<0.05)$. All statistical analyses were performed using GraphPad Prism 8 for MacOS X (Intuitive Software for Science, USA).

\section{RESULTS}

\section{Synthesis of Novel Lapachol-Containing Ruthenium Complex}

Two novel ruthenium complexes (1 and 2 ), with the general structures represented in Figure 1, were synthesized from the reaction of the precursor complex cis- $\left[\mathrm{RuCl}_{2}(\mathrm{dppm})(\mathrm{N}-\mathrm{N})\right]$, where $\mathrm{N}-\mathrm{N}=2,2^{\prime}$-bipyridine (bipy) or 1,10-phenanthroline (phen) and dppm $=1,1^{\prime}$-bis(diphenylphosphine)methane.

The structures for the complexes were confirmed by analytical and spectroscopic procedures described in Material and Methods section. The establishment of monocationic complexes was verified by molar conductivity measurements with a conductivity range between 17.22 and $59 \Omega^{-1} \mathrm{~cm}^{2} \mathrm{~mol}^{-1}$, which is consistent with the proposed structures. The elemental analyses of the complexes are coherent with their proposed formulas.

Infrared spectra of the complexes (1) and (2) confirmed the coordination of the Lap ligand. The band assigned to the $v(\mathrm{O}-\mathrm{H})$ stretching vibration of Lap was not observed in all complexes, indicating the deprotonation. The $v \mathrm{C}_{1}=\mathrm{O}$ and $v \mathrm{C}_{2}-\mathrm{O}$ of free Lap present values of 1,643 and $1,050 \mathrm{~cm}^{-1}$, respectively. In the complex (1) the $v \mathrm{C}_{1}=\mathrm{O}$ stretching vibration was shifted to lower frequencies, $1546 \mathrm{~cm}^{1}$, and the $v \mathrm{C}_{2}-\mathrm{O}$ shifted to $1103 \mathrm{~cm}^{-1}$ (Supplementary Figures $\mathbf{1}$ and 2 ). These results are in 
agreement with the change in electronic density after the coordination of the Lap to ruthenium that occurred in a bidentate mode by the oxygens atoms (16). Also, characteristic bands of a $P_{6}^{-}$counterion were observed at 840 and $555 \mathrm{~cm}^{-1}$. The same comportment was observed for complex (2).

The UV-vis spectra of both complexes showed bands around 268 and $293 \mathrm{~nm}$ characteristic of intraligand transitions $\left(\pi \rightarrow \pi^{\star}\right)$ of the bipy, phen, dppm, and Lap ligands. Also, bands around 350 to $600 \mathrm{~nm}$ was observed and can be assigned to metal-toligands charge transfer (MLCT) and, $\mathrm{n} \rightarrow \pi^{\star}$ transitions of quinone carbonyl groups $(8,39,40)$. The cyclic voltammograms showed a process related to $\mathrm{Ru}^{\mathrm{II}} / \mathrm{Ru}^{\mathrm{III}}$ oxidation at 1,188 and $1,176 \mathrm{mV}$, for complex (1) and (2), respectively, which are higher than the precursor complexes $(0.1-0.6 \mathrm{~V})$ (41). This observation indicates the higher stability of the complexes after the lapachol coordination to the metal.

In the ${ }^{31} \mathrm{P}\left\{{ }^{1} \mathrm{H}\right\}$ NMR spectra of complexes (1) and (2), it was observed a typical AB spin system with chemical shifts at 18.2/6.2 and 14.7/5.8 ppm for complex (1) and 18.3/7.1 and 14.9/6.5 ppm, for complex (2), indicating the nonequivalence of the phosphorus atoms. The duplication of phosphorus signals in the ${ }^{31} \mathrm{P}\left\{{ }^{1} \mathrm{H}\right\}$ NMR spectra are related to the presence of isomers in solution. In one isomer the phosphorus atom from the dppm ligand is trans to oxygen in the carbonyl of the lapachol and in another, the phosphorus atom is trans to the oxygen of enol (Supplementary Figures 3 and 4). The same behavior has been observed for others $\mathrm{Ru}(\mathrm{II})$ complexes with naphtoquinones as ligands $(23,40)$.

The ${ }^{1} \mathrm{H}$ NMR spectra of both complexes agree with the proposed structures of complexes. For complex (1), in the range 8.7 to $6.6 \mathrm{ppm}$ it was observed multiplets referent to $32 \mathrm{H}$ atoms of the bipy, dppm and Lap. There were observed multiplets at 5.5, 4.8, and 3.1 ppm of $\mathrm{CH}$ and $\mathrm{CH}_{2}$ groups of the aliphatic chains of Lap and dppm. Also, 1.5 to $1.4 \mathrm{ppm}$ was observed signals attributed to the two $\mathrm{CH}_{3}$ groups of Lap (Supplementary Figures 5 and 6).

The ${ }^{13} \mathrm{C}$ NMR spectra of both complexes displayed signals characteristic of $\mathrm{C} 1=\mathrm{O}$ and $\mathrm{C} 2-\mathrm{O}$ groups of Lap around 196 and $181 \mathrm{ppm}$. These signals were observed around 181 and 155 ppm in Lap free (Supplementary Figures 7 and 8). The displacement observed indicates the change in electronic density after the coordination of the Lap to ruthenium. It is noteworthy the stability of the complexes was evaluated before conducting the cell experiments. The stability was studied using $\mathrm{UV}$-vis and cyclic voltammograms experiments where both complexes demonstrated great stability in DMSO and DMSO/ Tris-HCl buffer ( $\mathrm{pH}$ 7.4) for a period of at least $72 \mathrm{~h}$ (Supplementary Figures 9 and 10).

\section{Partition Coefficient (log P) Study}

Lipophilicity is an essential physicochemical feature that predicts the pharmacokinetic/pharmacodynamic profile of new drug candidates drugs (42). The classical shake-flask method is widely recognized to determine the partition coefficient experimentally (43). The $\log \mathrm{P}(\mathrm{o} / \mathrm{w})$ values found were positive and ranged from $0.617 \pm 0.014$ to complex $(1)$ and $0.839 \pm 0.007$ to complex (2). The phenanthroline ligand might have granted higher lipophilicity to complex (2) which could be related to its cytotoxicity described below.

\section{Lapachol-Containing Ruthenium Complexes Display Potent Cytotoxicity Against a Panel of Cancer Cell Lines}

The potential of the complexes to disturb the viability of different histological types of cancer cell lines (A-375, A549, Caco-2, DU145, HepG2, PC-3, and MDA-MB-231) and two non-cancer cells (FGH and PNT-2) was assessed by Alamar blue ${ }^{\circledR}$ assay. Table 1 shows that both complexes presented enhanced cytotoxicity to different cancer cells and more potent activity than metal-free lapachol. The synthesized lapachol-containing ruthenium complexes exhibited remarkable cytotoxic properties against prostate cancer cells DU-145 and PC-3. Complex (1) presented $\mathrm{IC}_{50}$ values of 0.9 to $3.3 \mu \mathrm{M}$ and complex (2) presented $\mathrm{IC}_{50}$ values of 0.8 to $2.6 \mu \mathrm{M}$ for cancer cell lines DU-145 and A549, respectively. The complexes also displayed higher cytotoxic activity than cisplatin (Fauldcispla ${ }^{\circledR}$ ) and doxorubicin

TABLE 1 | Cytotoxic activity of lapachol-containing ruthenium complexes.

\begin{tabular}{|c|c|c|c|c|c|}
\hline & \multicolumn{5}{|c|}{$\mathrm{IC}_{50}[\mu \mathrm{M}]$} \\
\hline & DXR & CIS & (1) & (2) & Lp \\
\hline \multicolumn{6}{|l|}{ Cancer cells } \\
\hline A-375 & $3.7 \pm 0.6$ & $16.5 \pm 2.3$ & $2.5 \pm 0.6$ & $0.9 \pm 0.3$ & $>100.0$ \\
\hline A549 & $1.9 \pm 0.4$ & $11.9 \pm 0.6$ & $3.3 \pm 0.4$ & $2.6 \pm 0.1$ & $>100.0$ \\
\hline Caco-2 & $2.1 \pm 0.8$ & $17.4 \pm 0.3$ & $2.0 \pm 0.6$ & $1.2 \pm 0.3$ & $>100.0$ \\
\hline DU-145 & $2.3 \pm 0.5$ & $24.3 \pm 1.3$ & $0.9 \pm 0.2$ & $0.8 \pm 0.1$ & $>100.0$ \\
\hline HepG2 & $2.4 \pm 0.8$ & $14.1 \pm 0.5$ & $1.7 \pm 0.5$ & $1.5 \pm 0.2$ & $>100.0$ \\
\hline MDA-MB-231 & $2.1 \pm 0.7$ & $22.1 \pm 1.7$ & $2.1 \pm 0.4$ & $2.0 \pm 0.0$ & $>100.0$ \\
\hline PC-3 & $2.6 \pm 0.3$ & $10.8 \pm 1.1$ & $1.3 \pm 0.4$ & $1.1 \pm 0.3$ & $>100.0$ \\
\hline \multicolumn{6}{|c|}{ Non-cancer cells } \\
\hline FGH & $2.6 \pm 0.6$ & $11.4 \pm 0.5$ & $3.1 \pm 0.2$ & $2.5 \pm 0.3$ & $>100.0$ \\
\hline PNT-2 & $3.2 \pm 0.5$ & $9.5 \pm 0.3$ & $5.9 \pm 2.1$ & $6.8 \pm 1.5$ & $>100.0$ \\
\hline
\end{tabular}

Data are presented as the means \pm S.E.M. of $/ C_{50}$ values in $\mu M$ obtained by nonlinear regression from at the least three independent experiments performed in triplicate, measured by Alamar blue ${ }^{\circledR}$ assay after 24-h incubation. Cancer cells: A-375 (human malignant melanoma); A549 (human lung carcinoma); Caco-2 (human colorectal adenocarcinoma); DU-145 (human prostate adenocarcinoma); HepG2 (human hepatocellular carcinoma); MDA-MB-231 (human breast adenocarcinoma) and PC-3 (human prostate adenocarcinoma). Non-cancer cells: FGH (human mouth fibroblast) and PNT-2 (human prostate epithelial cells). Cisplatin (CIS), doxorubicin (DXR) and lapachol (Lp) were used as controls. 
(Fauldoxo ${ }^{\circledR}$ ). Doxorubicin presented $\mathrm{IC}_{50}$ values ranging from 1.9 to $3.7 \mu \mathrm{M}$ for cancer cell lines A549 and A-375, respectively. Cisplatin presented $\mathrm{IC}_{50}$ values varying from 10.8 to $24.3 \mu \mathrm{M}$ for cancer cell lines PC-3 and DU-145, respectively. The precursors cis- $\left[\mathrm{RuCl}_{2}(\mathrm{dppm})(\mathrm{bipy})\right]$ and cis- $\left.\left[\mathrm{RuCl}_{2}(\mathrm{dppm})(\mathrm{phen})\right]\right)$ had been previously tested and exhibited only weak cytotoxicity $\left(\mathrm{IC}_{50}>100 \mu \mathrm{M}\right)(23)$ and were not tested in the present work. The $\mathrm{IC}_{50}$ values for non-cancer cells were 3.1 and $5.9 \mu \mathrm{M}$ for the complex (1), and 2.5 and $6.8 \mu \mathrm{M}$ for the complex (2) for FGH and PNT-2 cells, respectively. In addition, the $\mathrm{IC}_{50}$ value for noncancer cells was 2.6 and $3.2 \mu \mathrm{M}$ for doxorubicin and 11.4 and 9.5 $\mu \mathrm{M}$ for cisplatin for FGH and PNT-2 cells, respectively.

The selectivity index (SI) measured for each complex has been presented in Supplementary Table 1. The SI was calculated using: $\mathrm{SI}=\mathrm{IC}_{50}$ [non-cancer cells]//C $\mathrm{I}_{50}$ [cancer cells]. The $\mathrm{SI}$ is a clear manner to estimate the therapeutic index of a drug and to identify safe drug candidates for further investigations (44). Complexes (1) and (2) were more cytotoxic and selective to prostate cancer cells DU-145. In fact, complex (2) showed higher selectivity for prostate cancer cells $(\mathrm{SI}=8.5$, for DU-145 and SI $=$ 6.2, for PC-3) when compared to prostate non-cancer cells. Furthermore, both complexes exhibit SI greater than displayed by the reference drugs cisplatin and doxorubicin. In a further round of experiments, the DU-145 was used as a cellular model, since displayed higher sensibility to treatments.

We also evaluate the complexes toward 3D cell cultures based on DU-145 cells. Interestingly, the prostate multicellular tumor spheroids (MCTSs) undergo alterations in their structure, indicating an effective permeability and, consequently cytotoxicity. The treatment of DU-145 MCTSs with complex (2) caused a decrease in the total spheroid area observed over time, which possibly resulted from cell apoptosis (Figure 2A). Subsequently, the treatment perturbed the cell aggregations, resulting in the presence of cell debris after 5 days, indicating an effective drug permeability and cytotoxicity in the 3D cultures (Figure 2B). The $\mathrm{IC}_{50}$ of the complexes (1) and (2) against the DU-145 MCTSs, were 2.4 and $1.9 \mu \mathrm{M}$, respectively, while cisplatin presented $\mathrm{IC}_{50}$ of $62.6 \mu \mathrm{M}$. The complex (2) was

A

Complex (2) in $\mu \mathbf{M}$
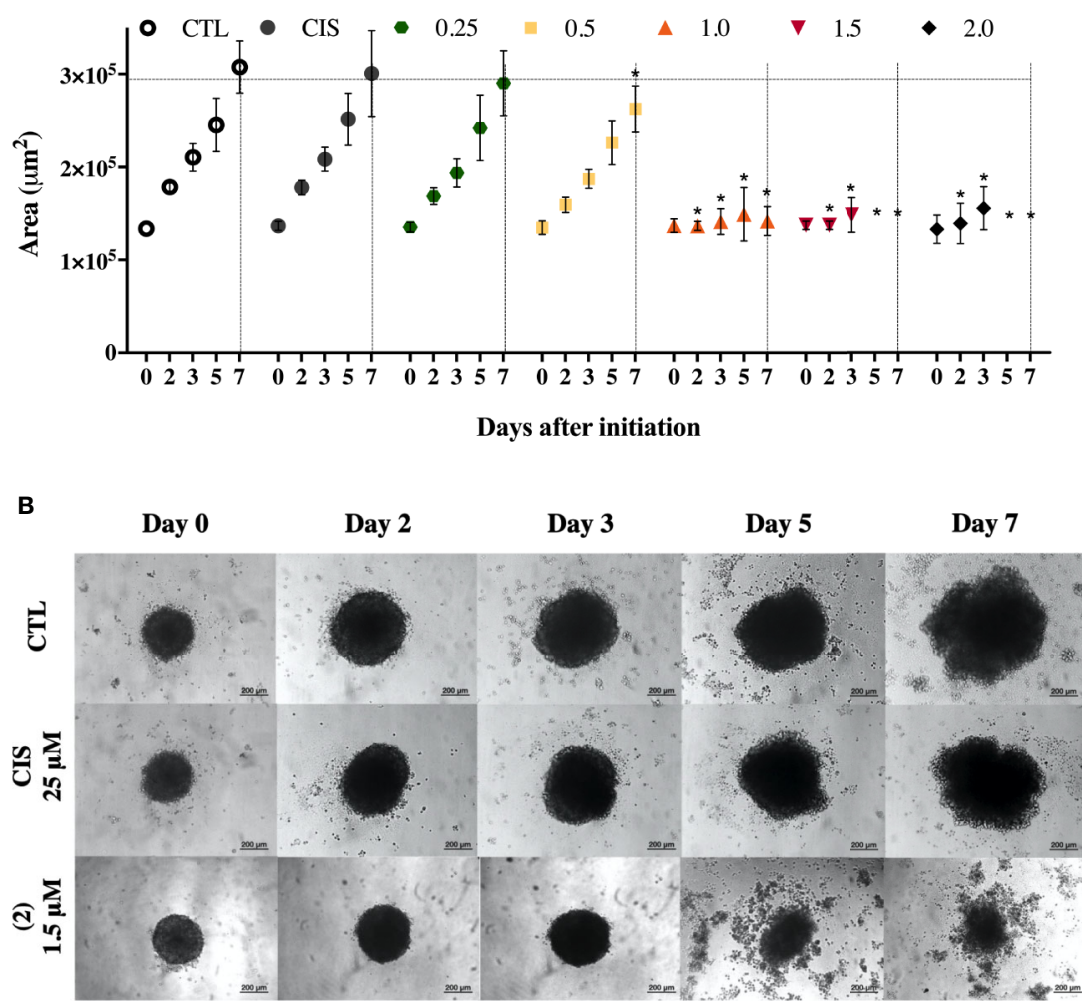

FIGURE 2 | Effect of the complex (2) in 3D in vitro model of multicellular tumor spheroids of DU-145 cells. (A) Routine monitoring of spheroid growth of DU-145 MCTSs treated with $0.25,0.5,1.0,1.5$, and $2.0 \mu \mathrm{M}$ of complex (2) without medium renewal followed by $50 \%$ medium exchange every $48 \mathrm{~h}$ for further culturing. Every feeding step results in a consecutive 1:2 dilution of the treatment. Graph represents spheroid volume growth kinetics of DU-145 MCTSs in liquid overlay culture. (B) DU-145 MCTSs were examined using inverted microscope (amplification, 200x), scale bar $=200 \mu \mathrm{m}$. The negative control (CTL) was treated with the vehicle $(0.1 \% \mathrm{DMSO})$ used for diluting the complex. Cisplatin $(\mathrm{CIS} 25 \mu \mathrm{M})$ were used as the positive controls. Data are presented as the mean \pm S.E.M. of three independent experiments performed in triplicate. ${ }^{*} p<0.05$ compared with the control by ANOVA followed by Dunnet's test. 
more potent than cisplatin at the least 32-fold, showing that its cytotoxic activity is effective in the tumor spheroids of DU145 cells.

\section{Lapachol-Containing Ruthenium Complexes Inhibits Cell Proliferation and Induces Cell Cycle G2/M Arrest in DU-145 Cells}

Both complexes inhibited colony formation at low cell density in a concentration-dependent manner, with partial inhibition at $0.125 \mu \mathrm{M}$ (Figure 3A). Mainly, the inhibitory effect of the complex (2) was greater than that of the complex (1) at the same concentrations. At concentrations of 0.125, 0.25, 0.5, 1.0, and $1.5 \mu \mathrm{M}$, the complex (1) reduced colony formation, presenting survival fractions (SF) of $65.1 \%, 35.1 \%, 18.3 \%$, $9.0 \%$, and $4.3 \%$, respectively. Complex (2), at the same concentrations, presented SF of $58.0 \%, 17.7 \%, 4.3 \%, 0 \%$, and $0 \%$, respectively. No significant $(p>0.05)$ decrease in the number of colonies was observed in control (DMSO $0.1 \% \mathrm{v} / \mathrm{v}$ ). Doxorubicin at $2.5 \mu \mathrm{M}$ and cisplatin at $25 \mu \mathrm{M}$ presented SF of $18.7 \%$ and $69.1 \%$, respectively. At concentrations of 1.0 and $1.5 \mu \mathrm{M}$ of complex (2), no colonies were visible at the plates (Figure 3B). The plating efficiency (PE) of untreated cells was higher than $76 \%$ for all replicates. Our findings revealed that both the complexes and doxorubicin were efficient in inhibiting cell proliferation after $24 \mathrm{~h}$ of treatment. Nonetheless, the same efficacy was not observed with cisplatin which presented SF of $69.1 \%$, suggesting that, in $24 \mathrm{~h}$, the complexes were more efficient than the metallodrug. Also, cell cycle analyses were carried out to investigate the relationship between inhibition of cell proliferation found in colony-formation assay and cell cycle arrest. The complex (2) increased cell number at the G2/M phase after $24 \mathrm{~h}$ treatment with increasing concentration, followed by decreased cell number at G0/G1 and S phases in DU-145 cells (Figure 3C).

To further evaluate the antiproliferative activity of complex (2), its effect on the expression of Aurora-B kinase was examined, since it is a mitotic checkpoint that performs a critical role during mitosis, guaranteeing correct chromosome segregation (45). Some studies also indicated that Aurora-B is overexpressed in human prostate adenocarcinoma and the inhibition of its kinase activity decreases considerably the cell proliferation (46). As shown in Figure 3D, we found that Aurora-B levels were downregulated after treatment of increasing concentrations of complex (2). Similar results were observed at the mRNA level as demonstrated on Table 2. Overall, these data indicated that the antiproliferative action of complex (2) in DU-145 prostate cells is associated with Aurora-B downregulation and cell cycle arrest in G2/M phase.
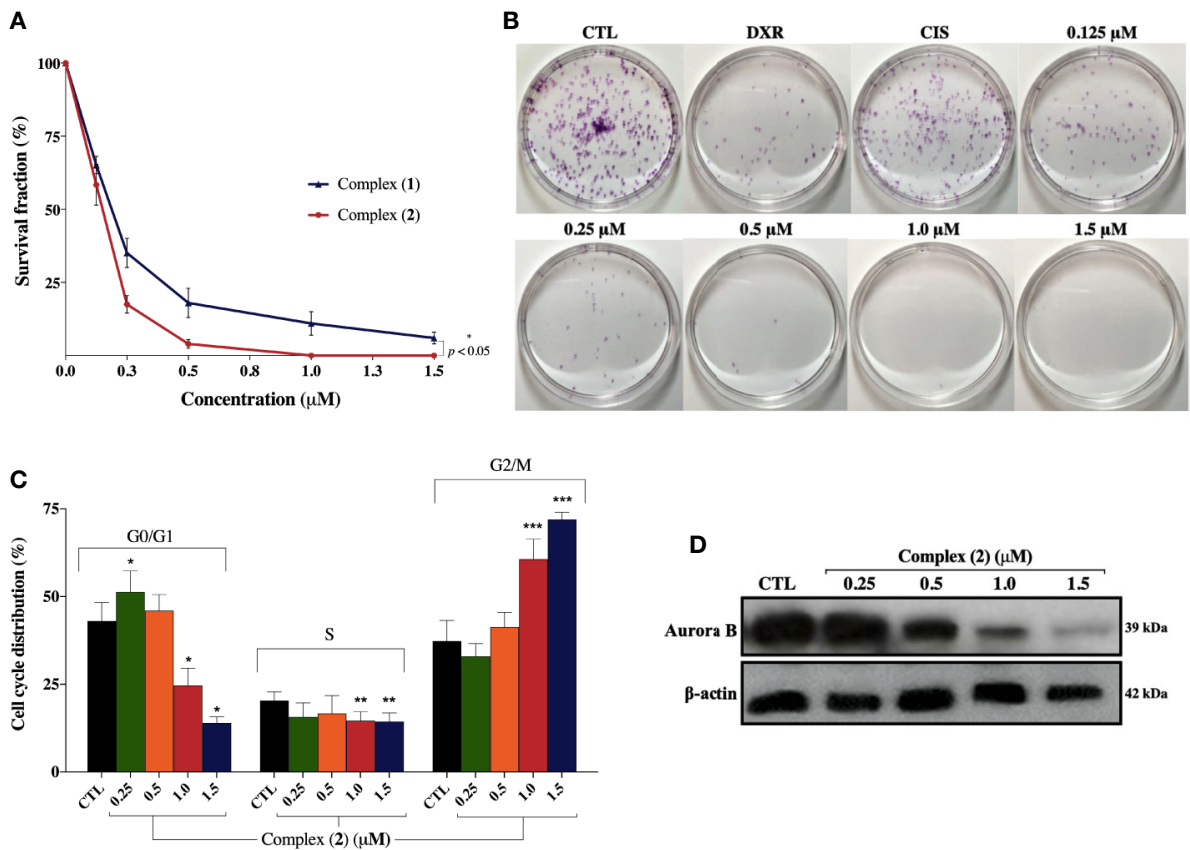

FIGURE 3 | Effect of lapachol-containing ruthenium complexes in DU-145 cell proliferation and cell cycle kinetics. (A) The survival fractions after $24 \mathrm{~h}$ treatment with 0.125; 0.25; 0.5; 1.0, and $1.5 \mu \mathrm{M}$ of complexes (1) and (2) against DU-145 cells. (B) Representative colony formation images of DU-145 cells after treatment with different concentrations of complex (2), DXR $(2.5 \mu \mathrm{M})$ and CIS $(25 \mu \mathrm{M})$. (C) Cell cycle distribution of DU-145 cells after treatment with complex (2) for 24 h. * ${ }^{* \star}$, and

*** indicate significant difference compared to the CTL in phase G0/G1, S, and G2/M, respectively. (D) Western blot analysis showing the expression status of Aurora-B in prostate adenocarcinoma cells after treatment with complex (2) for $24 \mathrm{~h}$. The densitometric analysis of gray bands is shown in Supplementary Figure 11. The negative control (CTL) was treated with the vehicle (DMSO $0.1 \% \mathrm{v} / \mathrm{v}$ ) used for diluting the complex. Data are presented as the mean \pm S.E.M. of three independent experiments performed in duplicate. Two-way ANOVA followed by Dunnett's post-test $(p<0.05)$. 
TABLE 2 | The effect of lapachol-containing ruthenium complex (2) on gene expression of DU-145 cells.

\begin{tabular}{|c|c|c|c|}
\hline Gene symbol & Description & Fold change & $P$ value \\
\hline$A K T 1$ & $A K T$ serine/threonine kinase 1 & -2.6 & 0.0008 \\
\hline AKT2 & $A K T$ serine/threonine kinase 2 & -2.6 & 0.0026 \\
\hline AURKA & Aurora kinase $\mathrm{A}$ & -5.3 & 0.0003 \\
\hline$A \cup R K B$ & Aurora kinase B & -11.1 & 0.0005 \\
\hline$A \cup R K C$ & Aurora kinase C & -3.0 & 0.0027 \\
\hline BCL2 & BCL2 apoptosis regulator & -4.1 & 0.0053 \\
\hline BIRC5 & Baculoviral IAP repeat containing 5 & -6.4 & 0.0031 \\
\hline CDC25A & Cell division cycle $25 \mathrm{~A}$ & -2.6 & 0.0042 \\
\hline$C D K 1$ & Cyclin dependent kinase 1 & -4.5 & 0.0029 \\
\hline$C D K 2$ & Cyclin dependent kinase 2 & -2.7 & 0.0034 \\
\hline CDK4 & Cyclin dependent kinase 4 & -4.6 & 0.0018 \\
\hline CDK5 & Cyclin dependent kinase 5 & -3.2 & 0.0003 \\
\hline EGFR & Epidermal growth factor receptor & -4.1 & 0.0008 \\
\hline ERBB2 & Erb-b2 receptor tyrosine kinase 2 & -2.4 & 0.0001 \\
\hline GSTP1 & Glutathione S-transferase PI 1 & -2.9 & 0.0005 \\
\hline HDAC8 & Histone deacetylase 8 & -1.8 & 0.0002 \\
\hline IGF1R & Insulin-like growth factor 1 receptor & -2.7 & 0.0012 \\
\hline MDM4 & MDM4 regulator of $\mathrm{P} 53$ & 2.8 & 0.0067 \\
\hline MTOR & Mechanistic target of rapamycin kinase & -3.8 & 0.0016 \\
\hline PARP1 & Poly(ADP-ribose) polymerase 1 & -2.7 & 0.0004 \\
\hline PARP2 & Poly(ADP-ribose) polymerase 2 & -3.0 & 0.0087 \\
\hline PDGFRB & Platelet-derived growth factor receptor beta & -2.0 & 0.0025 \\
\hline PIKЗСA & Phosphatidylinositol-4,5-bisphosphate 3-kinase alpha & -2.7 & 0.0032 \\
\hline PTGS2 & Prostaglandin-endoperoxide synthase 2 & 2.1 & 0.0006 \\
\hline TOP2A & DNA topoisomerase II alpha & -2.1 & 0.0006 \\
\hline TOP2B & DNA topoisomerase II beta & -2.8 & 0.0002 \\
\hline
\end{tabular}

\section{Lapachol-Containing Ruthenium Complexes Triggers Caspase-Mediated Apoptosis of DU-145 Cells}

To assess whether the cytotoxicity of the complexes is associated with cell death, we performed Annexin-V/PI double staining. The flow cytometry analysis showed that both complexes increased the number of cells in the early and late apoptosis stages (Q2 and Q4 quadrants) in a concentration-dependently manner (Figure 4A). For the complex (2), the population of apoptotic cells have increased remarkably in a concentrationdependent manner (5.9\% for control group, $11.8 \%$ for $0.25 \mu \mathrm{M}$, $22.7 \%$ for $0.5 \mu \mathrm{M}, 41.4 \%$ for $1.0 \mu \mathrm{M}$, and $70.2 \%$ for $1.5 \mu \mathrm{M}$ ) (Figure 4B). The complexes did not induce a significant increase of necrotic cells after the treatments. Cisplatin treatment of the DU-145 cells, at the fixed concentration of $25 \mu \mathrm{M}\left(\sim \mathrm{IC}_{50}\right)$ showed $19.5 \%$ of apoptotic cells. Therefore, a 100 -fold lower concentration of complex (2) was required for the same effect of cisplatin on DU-145 cells. To further determine whether extrinsic or intrinsic pathway the complex (2) induced apoptosis, we evaluated the expression of downstream apoptotic proteins by western blot. As shown in Figure 4C, there was an increase in the activation of cleaved caspase- $3,-9$, and PARP. Taken together, these data indicated that complex (2) induced apoptosis by activating the intrinsic pathway. Consequently, complex (2) was chosen for comprehensive studies of the mechanism of cell death.

\section{Lapachol-Containing Ruthenium Complex (2) Increase ROS Levels and Induce DNA Damage on DU-145 Cells}

To explore whether ROS are involved with the cytotoxicity of the complex (2), we used the Cellular ROS/Superoxide Detection Assay (Abcam, UK). Previously, the total ROS levels were assessed after $1,6,12$, and $24 \mathrm{~h}$ of incubation with $1.0 \mu \mathrm{M}$ of complex (2) $\left(\sim \mathrm{IC}_{50}\right)$ using $\mathrm{H}_{2} \mathrm{DCFDA}$ as a fluorescent dye to determine which time would be more appropriate for a ROS/ Superoxide analysis. The treatment of $24 \mathrm{~h}$ showed the highest increase of ROS (Supplementary Figure 12), so the ROS/ Superoxide detection was assessed after $24 \mathrm{~h}$ of exposure with several concentrations of complex (2). We determined that total ROS levels in DU-145 cells were significantly higher after the treatment (Figure 5A), suggesting the complex (2) exposure induced an oxidative stress response in the prostate tumor cells. It is demonstrably in Figure 5B, that the treatment induced ROS/ Superoxide accumulation in cells with the highest amount of ROS produced after exposure to $0.5 \mu \mathrm{M}$ of the complex (2). Moreover, at $1.5 \mu \mathrm{M}$ there was observed a decrease of ROS/ Superoxide levels, probably because increasing concentrations promotes cell death.

Besides, to verify the role of ROS in the trigger of cytotoxicity by complex (2), we used the ROS-scavenger NAC, an antioxidant that has been proven to display cytoprotective effects against ROS-induced cytotoxicity (47). The cotreatment with ROS 
A
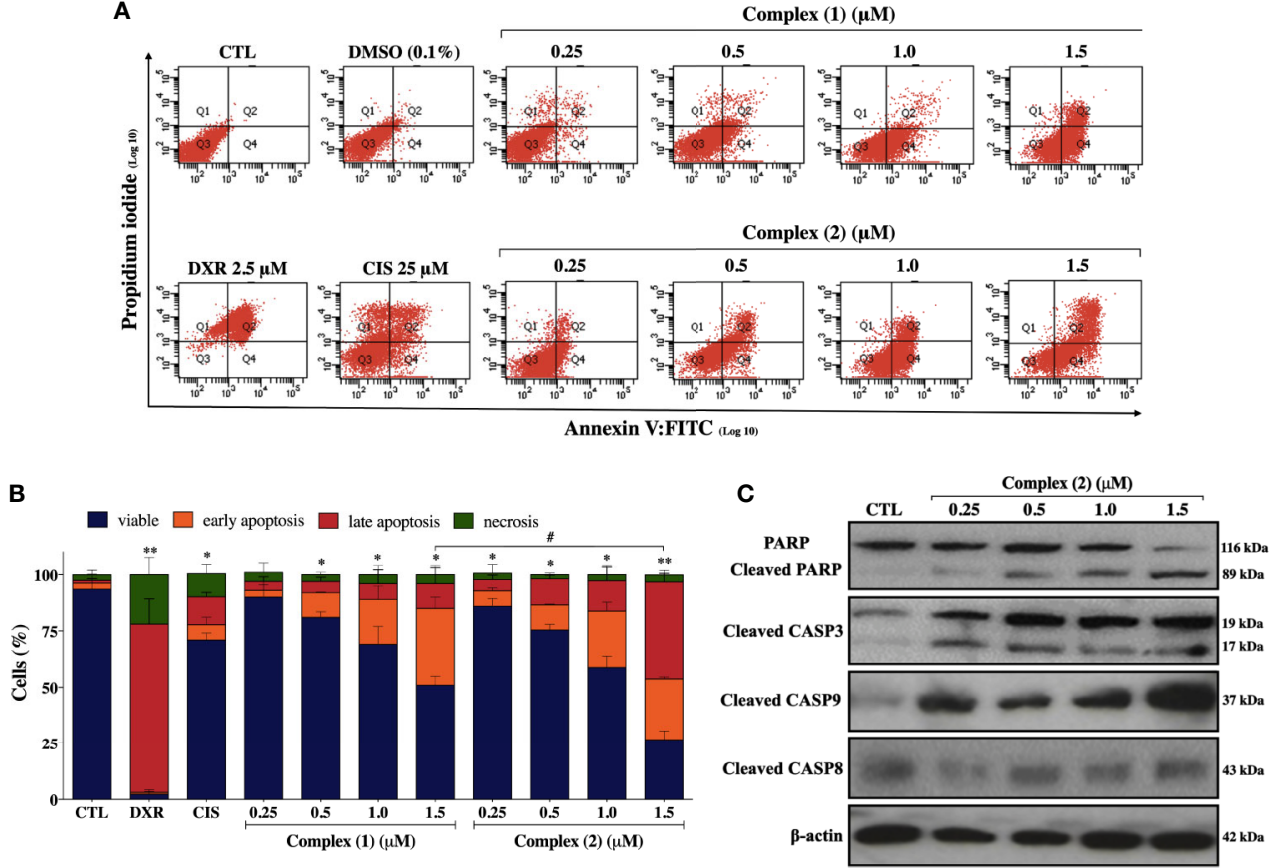

FIGURE 4 | Lapachol-containing ruthenium complexes induces apoptosis in DU-145 cells. (A) Representative flow cytometry dot plots show the presence of cells on viable (Q3), early apoptotic (Q4), late apoptotic (Q2) and necrotic (Q1) stages and, (B) showed the summary data determined by flow cytometry using annexin V-FITC/PI staining. Data are presented as the means \pm S.E.M. of three independent experiments performed in triplicate. Ten thousand events were evaluated per experiment, and cellular debris was omitted from the analysis. (C) Western blot analysis showing the expression and activation status of cleaved PARP as well as cleaved caspase-3 and -9 levels in prostate adenocarcinoma cells after treatment with complex (2) for $24 \mathrm{~h}$. The densitometric analysis of gray bands is shown in Supplementary Figure 11. The negative control (CTL) was treated with the vehicle (0.1\% DMSO) used for diluting the tested compound and, doxorubicin (DXR $2.5 \mu \mathrm{M})$ and cisplatin (CIS $25 \mu \mathrm{M})$ were used as drug control. Two-way ANOVA followed by Dunnett's post-test where, ${ }^{*} p<0.05$ vs. apoptotic cells in CTL; ${ }^{* *} p<0.01$ vs. apoptotic cells in CTL; ${ }^{\#} p<0.05$ apoptotic cells after $1.5 \mu \mathrm{M}$ of complex (1) vs. apoptotic cells after $1.5 \mu \mathrm{M}$ of complex (2).

scavenger inhibited the formation of intracellular ROS induced by complex (2) (Figures 5C, E) and, as expected, prevented the reduction of cell viability, as assessed by Alamar blue ${ }^{\circledR}$ assay (Figure 5D).

Considering that ROS are known to trigger DNA damage, the genotoxicity of the complex (2) on prostate cells were investigated by comet assay, a sensitive method for DNA strand break revelation. As shown in Figure 6A, in the control group, the nucleoids of DU-145 cells are round-shaped containing the undamaged DNA. However, after $24 \mathrm{~h}$ treatment, DU-145 cells exhibited well-formed comet tails by denatured DNA fragments migrating out of the cell nucleus during electrophoresis, which indicate the existence of DNA damage. We observed a significant DNA damage increase in DU145 nucleoids treated with complex (2) at $0.5 \mu \mathrm{M}$ (Figure 6B). Attempts to measure DNA damage after $24 \mathrm{~h}$ treatment with 1.0 $\mu \mathrm{M}$ of complex (2) gave inconsistent results with presence of nondetectable cell nuclei due the extensive cell death and DNA fragmentation during processing of DU-145 cells.

However, under the same experimental conditions, prostate normal cells showed no DNA damage after treatment with complex (2) at the same concentrations. Only at the maximum tested concentration of $6.0 \mu \mathrm{M}\left(\sim \mathrm{IC}_{50}\right)$ an increase in DNA damage was detected on PNT-2 cells (Supplementary Figure 13). These results indicate that complex (2) can enhance intracellular oxidative stress suggesting that apoptosis may be the principal mechanism of cell death triggered by ROSmediated DNA damage.

\section{Lapachol-Containing Ruthenium Complexes Interact With DNA}

As complex (2) was able to cause DNA damage, we studied the capability of these lapachol-containing ruthenium complexes to interact with ct-DNA by fluorescence and gel electrophoresis methods. DNA minor groove interaction was assessed by investigating the ability of the complexes to replace Hoechst 33258 from ct-DNA. To achieve this, the complexes were added to a DNA-Hoechst 33258 mixture to assess if the complexes compete with Hoechst and interact with DNA. If the complexes displace Hoechst from DNA, the fluorescence intensity of Hoechst decreases. Indeed, complex (2) could decrease the fluorescence of the Hoechst-DNA system by enhancing the concentration, indicating that it interacts with DNA by the minor groove and competes with Hoechst, removing it from DNA structure, thereby decreasing the fluorescence of the system (Figure 7A). Similar behavior was observed in complex (1) (Supplementary 


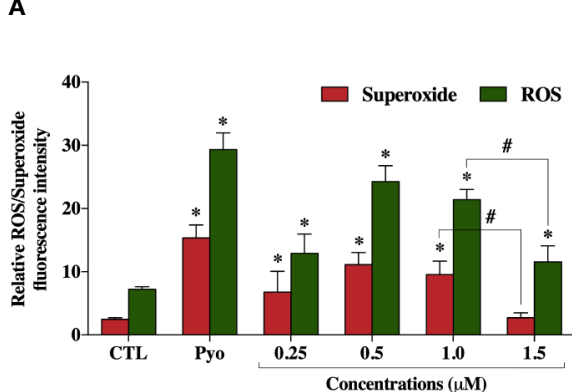

C

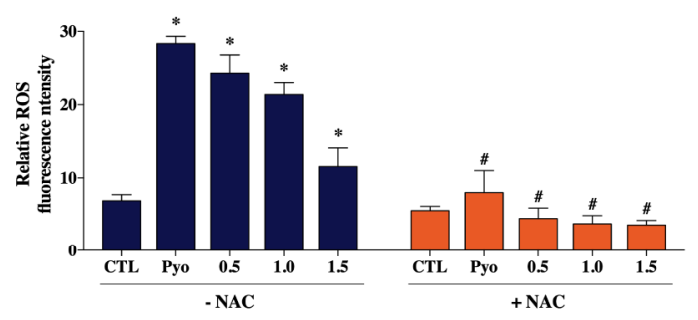

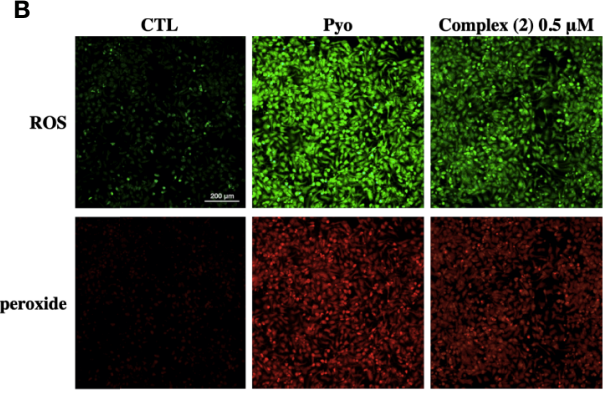

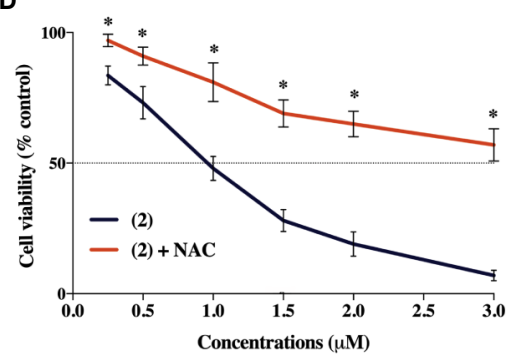

E
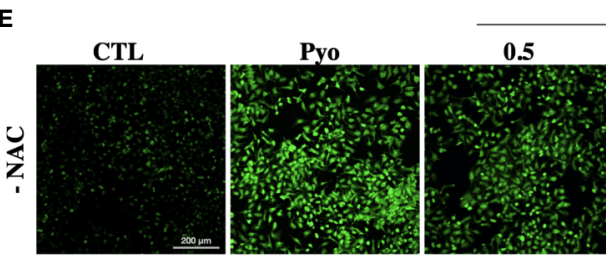

Complex (2) ( $\mu \mathrm{M})$
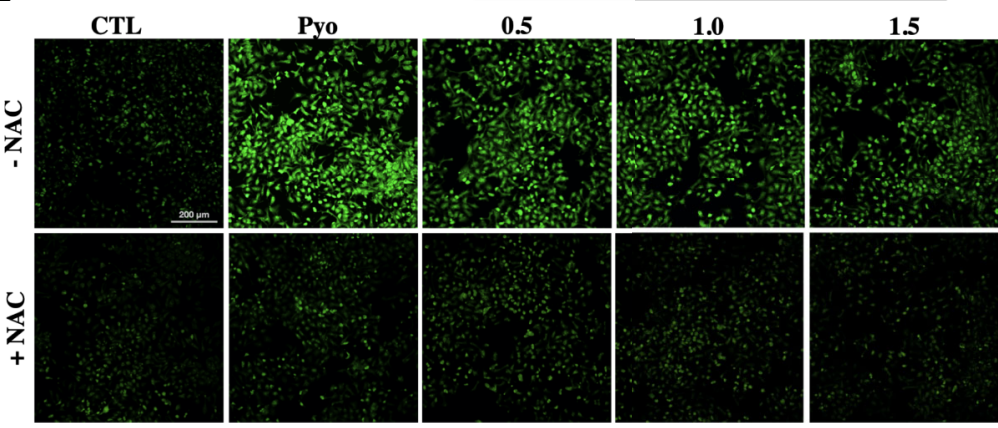

FIGURE 5 | Effect of the ruthenium complex (2) in the levels of reactive oxygen species (ROS) of DU-145 cells. (A) Quantitative analysis of relative ROS/ Superoxide fluorescence emission intensity $24 \mathrm{~h}$ after incubation with different concentrations of complex (2). (B) Cells labeled with the ROS-sensitive $f$ luorescent dyes using the Cellular ROS/Superoxide Detection Assay after exposure at $0.5 \mu \mathrm{M}$ of the complex (2). (C) ROS levels of DU-145 cells after $24 \mathrm{~h}$ treatment with complex (2) at 0.5, 1.0, and $1.5 \mu \mathrm{M}$ with or without the antioxidant NAC (5 mM). (D) Cell viability of DU-145 cells assessed by Alamar blue ${ }^{\circledR}$ assay after $24 \mathrm{~h}$ incubation with different concentrations of (2) with or without the antioxidant NAC (5 mM). (E) ROS scavenger NAC reduces the generation of intracellular ROS induced by complex (2). All fluorescence images were acquired using INCell Analyzer 2000 system at a total magnification of $200 \times($ scale bar $=$ $200 \mu \mathrm{m})$. The negative control (CTL) was treated with the vehicle (0.1\% DMSO) used for diluting the tested compounds. Pyocyanin (Pyo, $250 \mu \mathrm{M})$ was used as the positive control. Data are presented as the mean \pm S.E.M. of three independent experiments performed in triplicate or quadruplicate. ${ }^{*} p<0.05$ compared with the control by ANOVA followed Dunnet's test. ${ }^{\#} p<0.05$ compared with the respective treatment without NAC by ANOVA followed Dunnet's test.

Figure 14). In addition, complex (2) was able of influencing the mobility of the bands of pBR322 plasmid DNA in electrophoresis in agarose gel. Modification of the DNA structure causes interference in the migration of supercoiled DNA and a slight increase in the mobility of open circular DNA where both forms comigrate. The complex (2) was found to exhibit nuclease activity followed by conversion of supercoiled (SC) into linear (L), proposing single-strand DNA cleavage at $1.0 \mu \mathrm{M}$ (Figure 7B). Taken together, these findings suggest indicating that complex (2) directly interacts with DNA.

\section{Lapachol-Containing Ruthenium Complex (2) Alters Gene Expression in DU-145 Cells}

The expression of several genes associated with important cancer drug targets, such as cell proliferation, apoptosis, DNA damage repair, and epigenetics, was investigated in prostate cancer cells treated with $1.0 \mu \mathrm{M}$ of complex (2) for $12 \mathrm{~h}$ by qPCR using a 96well plate Human Cancer Drug Targets $\mathrm{RT}^{2}$ Profiler PCR Array $^{\circledR}$. To screen out inaccurate results a 1.8 -fold change in gene expression was applied as the cutoff point. The assessment shows a significant change in 26 genes $(30.9 \%)$ in the treated 


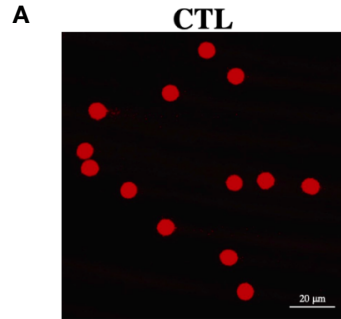

$0.125 \mu \mathrm{M}$

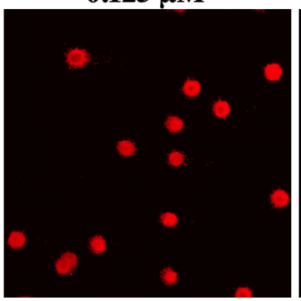

$0.5 \mu \mathrm{M}$

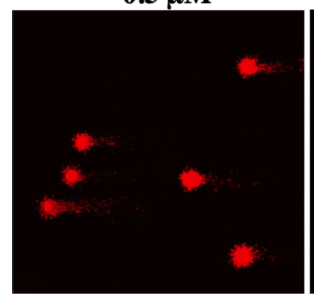

CTL+

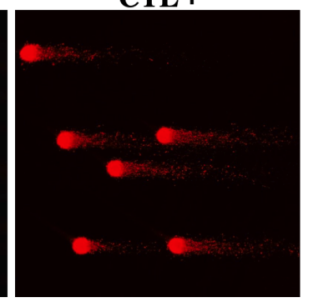

$0.25 \mu \mathrm{M}$

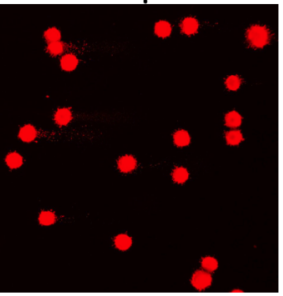

$1.0 \mu \mathrm{M}$

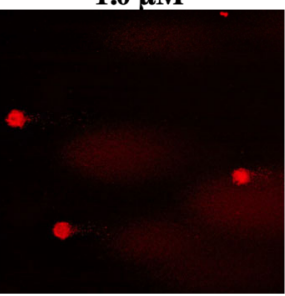

B

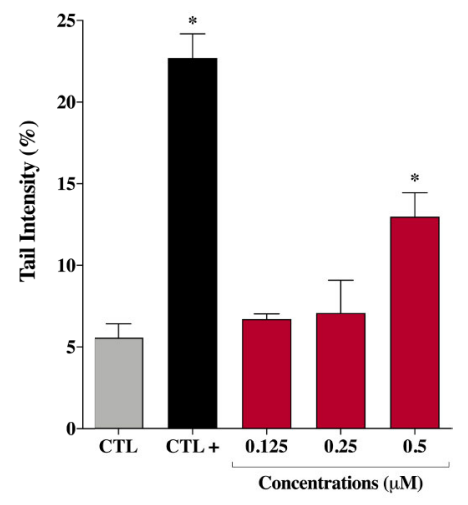

FIGURE 6 | Genotoxic effect of ruthenium complex (2) in DU-145 cells. (A) Representative image samples obtained by application of alkaline version of comet assay on DU-145 cells treated with complex (2) at $0.125,0.25,0.5$, and $1.0 \mu \mathrm{M}$ for $24 \mathrm{~h}$. (B) Bar graph represents the tail intensity (\%), which is directly correlated to damage DNA. The images were acquired with fluorescence microscopy at a total magnification of $400 \times(\mathrm{scale}$ bar $=20 \mu \mathrm{m})$ and correspond to a representative assay from three independent experiments. The negative control (CTL) was treated with the vehicle (0.1\% DMSO) used for diluting the tested compound and the positive control (CTL+) was treated with methyl methanesulfonate $(150 \mu \mathrm{M})$. Data are presented as the mean \pm S.E.M. of three independent experiments. ${ }^{*} p<0.05$ compared with the control by ANOVA followed Dunnet's test.

A

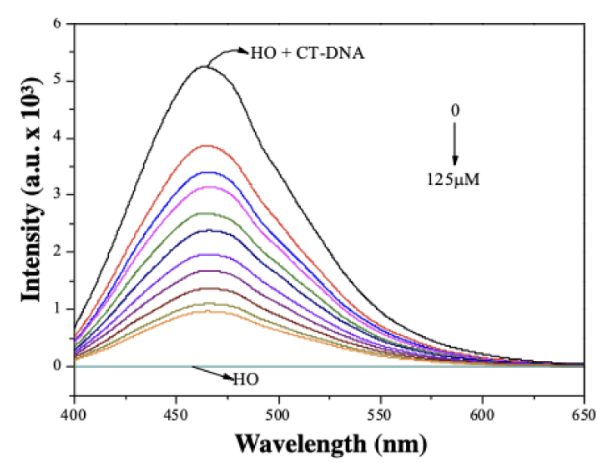

B

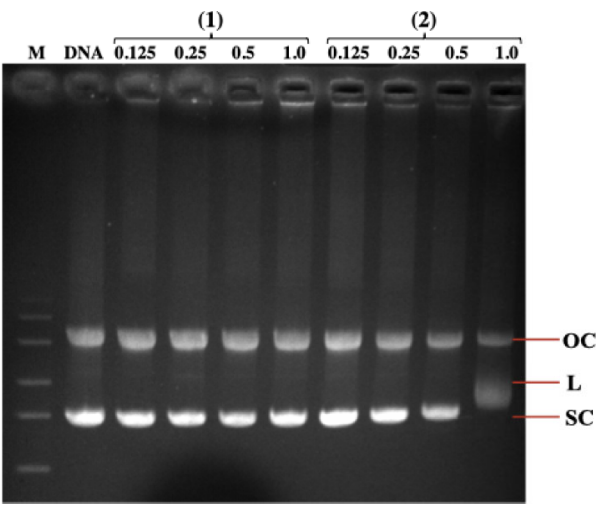

FIGURE 7 | Interaction of ruthenium-containing ruthenium complexes with DNA molecule. (A) Emission spectra of Hoechst (HO) $\left(2.7 \mu \mathrm{M}, \lambda_{\mathrm{ex}}=343 \mathrm{~nm}\right)$, CT-DNA $(125 \mu \mathrm{M})$ in presence of the complex (2) in different concentrations $(0-125 \mu \mathrm{M})$. (B) Agarose gel electrophoresis image of pBR322 plasmid DNA incubated with complexes (1) and (2). The pBR322 presents three forms, OC (open circular), L (linear) and SC (supercoiled). Lane 1 (M): molecular weight marker; lane 2 (DNA): pure pBR322 with DMSO; lanes 3-6 [complex (1)] and lanes 7-10 [complex (2)]. 
DU-145 cells compared to the untreated cells. A total of two genes were upregulated while 24 genes were downregulated (Table 2). The results demonstrate alterations in the expression of several genes involved in cellular pathways, especially apoptosis, cell cycle, and cell signaling. Among them, the genes BCL2 (-4.1-fold), BIRC5 (-6.4-fold), CDK1 (-4.5-fold), CDK4 (-4.6-fold), AURKA (-5.3-fold), AURKB (-11.1-fold), and $A U R K C$ (-3.0-fold) were downregulated in the cells treated with complex (2), while the genes MDM4 (2.8-fold) and PTGS2 (2.1fold) were upregulated.

Curiously, the complex (2) decreased markedly the expression of Aurora kinase genes, especially AURKB (-11.1fold). The inhibition of this class of serine/threonine kinases leads to stop cytokinesis and promote cell growth repression. This effect may indicate that the complex (2) inhibits the progression of cell cycle, resulting in its antiproliferative effect demonstrated by inhibiting the clonogenicity of DU-145 cells.

\section{DISCUSSION}

Lapachol is a well-characterized antitumor agent, capable of exerting significant growth inhibitory effects in several cancer models through ROS-mediated cytotoxicity (48). A broad range of biological and pharmacological activities has been discovered for lapachol and its derivatives highlighting its antitumor activity, firstly described in the early 1970s $(49,50)$. Nevertheless, this class of natural compounds had never been employed, from our best knowledge, as a ligand for the composition of ruthenium(II)/ phosphine complexes until the first studies of our research group $(8,51)$. Herein, novel lapachol-containing ruthenium(II)/ phosphine complexes were synthesized, characterized, and evaluated for their anticancer potential.

Ruthenium complexes have been extensively reported as potent cytotoxic and anti-metastatic agents in different cancer cells $(52,53)$; however, the incorporation of bioactive ligands enhances the biological activity of the metal complex formed. Ruthenium(II) complexes designed in the present study were tested against several cancer cells, presenting important cytotoxic activity. Other recent studies have shown that complexes of ruthenium with different phosphine ligands can induce cytotoxic activity against cancer cell lines (54-56). Lapachol and its derivatives showed antiproliferative effects in different histological types of cells, including ovary, colon, lung, breast, leukemia, esophageal, cervical, melanoma, and prostate $(7,57-$ 63). In this study, both lapachol-containing ruthenium(II) complexes displayed cytotoxic activity up to 100-fold higher than metal-free lapachol. Moreover, the complexes demonstrated selectivity for cancer cells greater than exhibited by the drugs cisplatin and doxorubicin, already used in the clinics for decades.

In $3 \mathrm{D}$ cell culture experiments, both complexes were also more potent in inducing cytotoxicity than cisplatin. Comparable with solid tumors in vivo, the hypoxic regions inside the spheroids decreases the velocity of cell division and diminishes the activity of chemotherapeutic drugs such as cisplatin (64).
In our outcomes, the treatment with complex (2) provoked alterations in the shape of the spheroid, such as loss of circularity and consequent disaggregation. These findings are consistent with an effective permeability of the complex inside the spheroids.

Regarding their mechanism of action, complex (2) induce caspase-dependent apoptosis on DU-145 cells as observed by externalization of phosphatidylserine, DNA fragmentation, and caspase- 3 and -9 activation. Besides, our data showed that complex (2) could suppress cell proliferation that was accompanied by an accumulation of cells in the G2/M phase, which is consistent with the downregulation of Aurora-B kinase in prostate cancer cells. The G2/M checkpoint blocks cells from entering mitosis with genomic DNA damage, granting an opportunity for repair or stopping the proliferation of damaged cells (65). According to the analysis, complex (2) increased the proportion in the G2/M phase and decreased the cell proportion in G0/G1 and S phases in DU-145 cells. Further, gene and protein expression analysis showed that complex (2) led to a decrease in the expression of the Aurora kinase family, an important group of enzymes that execute an essential function in cell cycle progression especially at the mitotic stage. In the current study, we show that the treatment with complex (2) decreased the expression of Aurora-B, followed by antiproliferative effects in DU-145 cells, such as loss of its clonogenicity. Studies also revealed that Aurora-B regulates the G2/M phase transition through several key factors at the transcriptional level $(66,67)$. Overexpression of Aurora-B has been observed in various cancers and has been associated with a worse prognostic for cancer patients (68). Besides, Aurora-B expression directly correlates with Gleason grade, an important prognostic factor in prostate cancer (46).

Some studies propose that Aurora-B expression is inhibited by proteins of DNA repair system (69-71). The repair of DNA damage is started by sensory proteins that accumulate at the sites of damage. This accumulation activates a cascade of phosphorylation that modifies the chromatin and allows access to DNA repair factors. The non-homologous end joining (NHEJ) factor $\mathrm{Ku} 70$ is phosphorylated in serine 155 in response to the DNA damage (72). When activated, Ku70 S155 interacts with Aurora B inhibiting its kinase activity, providing time to complete DNA repair. Taken together, these shreds of evidence suggest that complex (2) induces oxidative DNA damage and inhibits Aurora-B on DU-145 cells. The principal mechanism of action is the ability of this complex to increase the generation of ROS, thereby being responsible for its ability to cause DNA damage and trigger apoptosis through the intrinsic pathway.

As mentioned above, lapachol induces the generation of ROS, which damages DNA and afterward promotes apoptosis. It is widely known that ruthenium(II) complexes could lead to apoptosis through ROS-mediated pathway in cancer cells $(73,74)$. ROS are recognized as critical upstream molecules in the regulation of apoptosis and cancer initiation. Basal levels of ROS can operate as signals to promote cell proliferation, whereas high levels of ROS can damage cellular components such as DNA, leading to cell apoptosis (75). Hence, considering that 
ruthenium(II) complexes and lapachol have been reported as ROS inductor agents, we evaluated the ROS level in cells treated with lapachol-containing ruthenium complexes. Actually, complex (2) could also increase general ROS and superoxide anion levels. Interestingly, the cotreatment with ROS inhibitor NAC remarkably suppressed the generation of ROS and prevented the reduction of cell viability. Additionally, complex (2) induced DNA damage on DU-145 cells and directly interacts with DNA, suggesting that this compound trigger caspasedependent apoptosis through ROS-mediated DNA damage in DU-145 prostate cells.

The mechanisms underlying the cytotoxic and antiproliferative activities of complex (2) were evaluated at the level of mRNA expression of diverse genes. Notably, it was detected the decreasing expression of genes associated with apoptosis, such as BCL2 and BIRC5, and genes involved in the cell cycle transition, such as CDK1,CDK4, AURKA, AURKB, and $A U R K C$.

BCL-2 family proteins suppress apoptosis by binding with $\mathrm{BAX}$ and $\mathrm{BAK}$ proteins that can form pores in the mitochondria and promote the release of cytochrome c, triggering the apoptotic process (76). Lima et al. (77) demonstrated that ruthenium complexes containing phosphine ligands considerably decrease the expression of the BCL2 gene in sarcoma-180 cells. This effect was associated with the loss of mitochondrial transmembrane potential and activation of caspases. Complex (2) also decreased the expression of the BIRC5 gene on DU-145 cells, which was 6.4 times less expressed than the untreated cells. BIRC5 encodes a protein called survivin, which became an attractive drug target for anticancer therapies. Studies showed that blocking the transcription of the BIRC5 gene in prostate cells inhibits the growth of xenografted PC-3 tumors in mice (78). Further, Hurtado et al. (79) reported that copper(II) complexes suppressed the expression of BIRC5 at both mRNA and protein levels in pancreatic cancer cells. Furthermore, complex (2) promoted dysregulation of several genes that encode CDKs, especially CDK4, a protein commonly overexpressed in prostate cancer (80). Agents that selectively regulate the activity of the CDK4 gene have been described in the literature for their ability to inhibit cell proliferation with tolerable toxic effects (81).

We also observed a considerable decrease in the expression of Aurora kinase genes, a family of kinases normally altered in different types of tumors, and consequently, a therapeutic target for cancer (82). Aurora-A and Aurora-B are usually overexpressed in primary prostate cancers and such expression patterns are associate with tumorigenicity, tumor progression, and clinical staging (83). Protein Aurora-B was also downregulated after treatment with increased concentrations of complex (2). Aurora-B plays a crucial role in the Chromosomal Passenger Complex (CPC), a complex necessary for binding of microtubules to the kinetochore of chromosomes, in order to ensure adequate fusion for cell division (84). Addepalli et al. (85) demonstrated that the knockout of the AURKB gene mediated by RNAi substantially inhibits the proliferation of PC-3 prostate tumor cells, inducing apoptosis in vitro. In fact, other studies have shown that inhibition of Aurora-B has an antiproliferative effect and cause regression of prostate cancer in vivo $(46,86,87)$. Therefore, complex (2) can represent a promising candidate for modulation of $A U R K B$ expression, opening new trails for anticancer therapy.

It was further observed the upregulation of MDM4 and PTGS2 genes in the treated cells. In the present data, complex (2) increased the levels of ROS/Superoxide, which could directly modulate the expression of PTGS2 through the MAPK/ERK cascade on damaged cells (88). Therefore, the increase in PTGS2 expression is related to the cellular response to high levels of ROS in DU-145 after complex (2) exposure. The strength of complex (2) generates ROS is also associated with increased expression of MDM4, a key regulator of P53 that plays an important role in regulating genomic instability (89). Increased expression of MDM4 is in agreement with the ROS-mediated DNA damage induced by complex (2) as well as the elevated apoptosis by activating the intrinsic (mitochondrial) pathway. Taken together, these results showed that complex (2) can regulate several genes associated with the proliferation of prostate adenocarcinoma cells. The regulation of these genes strengthens the mechanism of action of complex (2), which appears to be involved in the interruption of the cell cycle in $\mathrm{G} 2 / \mathrm{M}$ in response to ROSmediated DNA damage and the induction of caspasedependent apoptosis.

In summary, our study revealed that lapachol-containing ruthenium complexes (1) and (2) exhibited remarkable antiproliferative activities to human prostate adenocarcinoma cells. We found that complex (2) significantly induced G2/M cell cycle arrest, induce caspase-dependent apoptosis, and provoke ROS-mediated DNA damage. Moreover, the expression of various genes, including cell division cycle and apoptosis was regulated under treatment. These encouraging results warrant further studies to enhance the knowledge of the anticancer properties of these complexes, as well as identify their pharmacokinetics/pharmacodynamics properties in an attempt to expand the field of prostate anticancer chemotherapy.

\section{DATA AVAILABILITY STATEMENT}

The datasets presented in this study can be found in online repositories. The names of the repository and accession number can be found in the Supplementary Material.

\section{AUTHOR CONTRIBUTIONS}

Conceived and designed the experiments: RG, AB and FP. Performed the synthesis and structural characterization of the novel complexes: KO and AG. Performed the cellular and molecular effects of the novel complexes: RG, PS, and AA. Analyzed the data and wrote the manuscript: RG, PS, AA, and KO. Provided the technical and financial support: $R G, A B$, and FP. All authors contributed to the article and approved the submitted version. 


\section{ACKNOWLEDGMENTS}

The authors gratefully acknowledge the financial support from the São Paulo Research Foundation (FAPESP, Grants 16/224297, 17/15850-0, 18/00163-0 and 21/05017-5), Coordinating Committee for Advancement of Higher Education Staff in Brazil (CAPES) and National Council for Scientific and Technological Development (CNPq, Grants 151032/2020-3). The authors also thank Prof. Lusânia M. G. Antunes from University of São Paulo for her special assistance. The author

\section{REFERENCES}

1. Rawla P. Epidemiology of Prostate Cancer. World J Oncol (2019) 10:63-89. doi: 10.14740/wjon 1191

2. Teoh JYC, Hirai HW, Ho JMW, Chan FCH, Tsoi KKF, Ng CF. Global Incidence of Prostate Cancer in Developing and Developed Countries With Changing Age Structures. PloS One (2019) 14:1-9. doi: 10.1371/journal. pone. 0221775

3. Ferlay J, Soerjomataram I, Dikshit R, Eser S, Mathers C, Rebelo M, et al. Cancer Incidence and Mortality Worldwide: Sources, Methods and Major Patterns in GLOBOCAN 2012. Int J Cancer (2015) 136:E359-86. doi: 10.1002/ijc.29210

4. Tiwari R, Manzar N, Bhatia V, Yadav A, Nengroo MA, Datta D, et al. Androgen Deprivation Upregulates SPINK1 Expression and Potentiates Cellular Plasticity in Prostate Cancer. Nat Commun (2020) 11:384. doi: 10.1038/s41467-019-14184-0

5. Hussain H, Green IR. Lapachol and Lapachone Analogs: A Journey of Two Decades of Patent Research (1997-2016). Expert Opin Ther Pat (2017) 27:1111-21. doi: 10.1080/13543776.2017.1339792

6. Spoerlein-Guettler C, Mahal K, Schobert R, Biersack B. Ferrocene and (Arene)Ruthenium(II) Complexes of the Natural Anticancer Naphthoquinone Plumbagin With Enhanced Efficacy Against Resistant Cancer Cells and a Genuine Mode of Action. J Inorg Biochem (2014) 138:64-72. doi: 10.1016/j.jinorgbio.2014.04.020

7. Mendes Miranda SE, de Alcântara Lemos J, Fernandes RS, De O Silva J, Ottoni FM, Townsend DM, et al. Enhanced Antitumor Efficacy of LapacholLoaded Nanoemulsion in Breast Cancer Tumor Model. BioMed Pharmacother (2021) 113:110936. doi: 10.1016/j.biopha.2020.110936

8. Oliveira KM, Corrêa RS, Barbosa MIF, Ellena J, Cominetti MR, Batista AA. Ruthenium (II)/Triphenylphosphine Complexes: An Effective Way to Improve the Cytotoxicity of Lapachol. Polyhedron (2017) 130:108-14. doi: $10.1016 /$ j.poly.2017.04.005

9. Oramas-Royo S, Torrejón C, Cuadrado I, Hernández-Molina R, Hortelano S, Estévez-Braun A, et al. Synthesis and Cytotoxic Activity of Metallic Complexes of Lawsone. Bioorg Med Chem (2013) 21:2471-7. doi: 10.1016/ j.bmc.2013.03.002

10. Kosiha A, Parthiban C, Ciattini S, Chelazzi L, Elango KP. Metal Complexes of Naphthoquinone Based Ligand: Synthesis, Characterization, Protein Binding, Dna Binding/Cleavage and Cytotoxicity Studies. J Biomol Struct Dyn (2017) 1102:1-12. doi: 10.1080/07391102.2017.1413423

11. Avendaño C, Menéndez JC. Medicinal Chemistry of Anticancer Drugs. Elsevier Sci (2008) 35:4376-77. doi: 10.1016/B978-0-444-52824-7.00001-9

12. Kubanik M, Kandioller W, Kim K, Anderson RF, Klapproth E, Jakupec MA, et al. Towards Targeting Anticancer Drugs: Ruthenium(II)-Arene Complexes With Biologically Active Naphthoquinone-Derived Ligand Systems. Dalton Trans (2016) 45:13091-103. doi: 10.1039/c6dt01110a

13. Rajendran M. Quinones as Photosensitizer for Photodynamic Therapy: ROS Generation, Mechanism and Detection Methods. Photodiagn Photodyn Ther (2015) 13:175-87. doi: 10.1016/j.pdpdt.2015.07.177

14. Ourique F, Kviecinski MR, Felipe KB, Correia JFG, Farias MS, Castro LSEPW, et al. DNA Damage and Inhibition of Akt Pathway in MCF-7 Cells and Ehrlich Tumor in Mice Treated With 1,4-Naphthoquinones in Combination With Ascorbate. Oxid Med Cell Longev (2015) 2015:495305. doi: 10.1155/ 2015/495305
RG heartily acknowledges Prof. Eliana A. Varanda from the School of Pharmaceutical Sciences of UNESP for providing his firsties guidances in the fascinating field of Science.

\section{SUPPLEMENTARY MATERIAL}

The Supplementary Material for this article can be found online at: https://www.frontiersin.org/articles/10.3389/fonc.2021. 682968/full\#supplementary-material

15. Kandioller W, Balsano E, Meier SM, Jungwirth U, Göschl S, Roller A, et al Organometallic Anticancer Complexes of Lapachol: Metal Centre-Dependent Formation of Reactive Oxygen Species and Correlation With Cytotoxicity. Chem Commun (Camb) (2013) 49:3348-50. doi: 10.1039/c3cc40432c

16. Oliveira KM, Peterson EJ, Carroccia MC, Cominetti MR, Deflon VM, Farrell NP, et al. $\mathrm{Ru}(\mathrm{II})$-Naphthoquinone Complexes With High Selectivity for TripleNegative Breast Cancer. Dalt Trans (2020) 49:16193-203. doi: 10.1039/d0dt01091j

17. Zu X, Xie X, Zhang Y, Liu K, Bode AM, Dong Z, et al. Lapachol Is a Novel Ribosomal Protein S6 Kinase 2 Inhibitor That Suppresses Growth and Induces Intrinsic Apoptosis in Esophageal Squamous Cell Carcinoma Cells. Phyther Res (2019) 33:2337-46. doi: 10.1002/ptr.6415

18. Martino T, Magalhães FCJ, Justo GA, Coelho MGP, Netto CD, Costa PRR, et al. The Pterocarpanquinone Lqb-118 Inhibits Tumor Cell Proliferation by Downregulation of c-Myc and Cyclins D1 and B1 mRNA and Upregulation of P21 Cell Cycle Inhibitor Expression. Bioorg Med Chem (2014) 22:3115-22. doi: 10.1016/j.bmc.2014.04.025

19. Lin K, Zhao ZZ, Ben B, XJ H, Wang JQ. Applications of Ruthenium Complex in Tumor Diagnosis and Therapy. Front Pharmacol (2018) 9:1323. doi: 10.3389/fphar.2018.01323

20. Zeng L, Gupta P, Chen Y, Wang E, Ji L, Chao H, et al. The Development of Anticancer Ruthenium(II) Complexes: From Single Molecule Compounds to Nanomaterials. Chem Soc Rev (2017) 46:5771-804. doi: 10.1039/c7cs00195a

21. Teixeira TM, Arraes IG, Abreu DC, Oliveira KM, Correa RS, de Paula Silveira Lacerda E, et al. Ruthenium Complexes Show Promise When Submitted to Toxicological Safety Tests Using Alternative Methodologies. Eur J Med Chem (2021) 216:113262. doi: 10.1016/j.ejmech.2021.113262

22. De Grandis RA, de Camargo MS, da Silva MM, Lopes ÉO, Padilha EC, Resende FA, et al. Human Topoisomerase Inhibition and DNA/BSA Binding of $\mathrm{Ru}(\mathrm{II})-\mathrm{SCAR}$ Complexes as Potential Anticancer Candidates for Oral Application. BioMetals (2017) 30:321-34. doi: 10.1007/s10534-017-0008-z

23. De Grandis RA, da Silva dos Santos W, de Oliveira KM, Machado ART, Aissa AF, Batista AA, et al. Novel Lawsone-Containing Ruthenium(II) Complexes: Synthesis, Characterization and Anticancer Activity on 2D and 3D Spheroid Models of Prostate Cancer Cells. Bioorg Chem (2019) 85:455-68. doi: 10.1016/ j.bioorg.2019.02.010

24. Camargo MS, da Silva MM, Correa RS, Vieira SD, Castelli S, D'Anessa I, et al. Inhibition of Human DNA Topoisomerase IB by Nonmutagenic Ruthenium (II)-Based Compounds With Antitumoral Activity. Metallomics (2016) 8:17992. doi: 10.1039/C5MT00227C

25. Camargo MS, De Grandis RA, da Silva MM, da Silva PB, Santoni MM, Eismann $\mathrm{CE}$, et al. Determination of In Vitro Absorption in Caco-2 Monolayers of Anticancer Ru(II)-Based Complexes Acting as Dual Human Topoisomerase and PARP Inhibitors. BioMetals (2018) 32:89-100. doi: 10.1007/s10534-018-0160-0

26. da Silva MM, de Camargo MS, Castelli S, de Grandis RA, Castellano EE, Deflon VM, et al. Ruthenium(II)-Mercapto Complexes With Anticancer Activity Interact With Topoisomerase Ib. J Braz Chem Soc (2020) 31:53649. doi: 10.21577/0103-5053.20190214

27. Moreira DRM, de Sá MS, Macedo TS, Reys JRM, Santana AEG, Silva TL, et al. Evaluation of Naphthoquinones Identified the Acetylated Isolapachol as a Potent and Selective Antiplasmodium Agent. J Enzym Inhib Chem (2014) 30:615-21. doi: 10.3109/14756366.2014.958083

28. Sullivan BP, Salmon DJ, Meyer TJ. Mixed Phosphine 2,2'-Bipyridine Complexes of Ruthenium. Inorg Chem (1978) 17:3334-41. doi: 10.1021/ ic50190a006 
29. Batista AA, Santiago MO, Donnici CL, Moreira IS, Healy PC, Berners-Price SJ, et al. Electrochemical and Spectroscopic Studies on $\mathrm{RuCl}_{2}\left(\mathrm{PPh}_{3}\right)_{2}(\mathrm{~N})_{2}$ and $\mathrm{RuCl}_{2}$ $\left(\mathrm{PPh}_{3}\right)_{2}(\mathrm{~N}-\mathrm{N})$ Complexes (N=Pyridine Derivatives and $\mathrm{N}-\mathrm{N}=$ phenanthroline or Bipyridine Derivatives). X-ray Structure of $\mathrm{Rucl}_{2}\left(\mathrm{Pph}_{3}\right)_{2}(\mathrm{Phen})$. Polyhedron (2001) 20:2123-8. doi: 10.1016/S0277-5387(01)00744-6

30. Baka E, Comer JEA, Takács-Novák K. Study of Equilibrium Solubility Measurement by Saturation Shake-Flask Method Using Hydrochlorothiazide as Model Compound. J Pharm BioMed Anal (2008) 46:335-41. doi: 10.1016/ j.jpba.2007.10.030

31. Bal-Price A, Coecke S. Guidance on Good Cell Culture Practice (Gccp). In: Cell Culture Techniques. New York: Springer (2011) 1:1-25. doi: 10.1007/9781-61779-077-5_1

32. Page S. Ruthenium Compounds as Anticancer Agents. Educ Chem (2012) 49:26-9. doi: 10.2174/092986706776360941

33. Friedrich J, Seidel C, Ebner R, Kunz-Schughart LA. Spheroid-Based Drug Screen: Considerations and Practical Approach. Nat Protoc (2009) 4:309-24. doi: 10.1038/nprot.2008.226

34. Franken NP, Rodermond HM, Stap J, Haveman J, van Bree C. Clonogenic Assay of Cells In Vitro. Nat Protoc (2006) 1:2315-9. doi: 10.1038/nprot. 2006.339

35. Cummings BS, Wills LP, Schnellmann RG. Measurement of Cell Death in Mammalian Cells. Curr Protoc Phamacol (2004) 1:1-30. doi: 10.1002/ 0471141755.ph1208s25.Measurement

36. Wang H, Joseph JA. Quantifying Cellular Oxidative Stress by Dichlorofluorescein Assay Using Microplate Reader. Free Radic Biol Med (1999) 27:612-6. doi: 10.1016/S0891-5849(99)00107-0

37. Tice RR, Agurell E, Anderson D, Burlinson B, Hartmann A, Kobayashi H, et al. Single Cell Gel/Comet Assay: Guidelines for In Vitro and In Vivo Genetic Toxicology Testing. Environ Mol Mutagen (2000) 35:206-21. doi: 10.1002/ (SICI) 1098-2280(2000)35:3<206::AID-EM8>3.0.CO;2-J

38. Marmur J. A Procedure for the Isolation of Deoxyribonucleic Acid From Micro-Organisms. J Mol Biol (1961) 3:IN1-218. doi: 10.1016/S0022-2836(61) 80047-8

39. Oliveira KM, Liany L-D, Corrêa RS, Deflon VM, Cominetti MR, Batista AA. Selective $\mathrm{Ru}(\mathrm{II}) /$ lawsone Complexes Inhibiting Tumor Cell Growth by Apoptosis. J Inorg Biochem (2017) 176:66-76. doi: 10.1016/j.jinorgbio. 2017.08.019

40. Oliveira K, Peterson EJ, Carroccia M, Cominetti MR, Deflon VM, Farrell NP, et al. $\mathrm{Ru}(\mathrm{II})$-Naphthoquinone Complexes With High Selectivity for Triple Negative Breast Cancer. Dalt Trans (2020) 40:16193-203. doi: 10.1039/ D0DT01091J

41. Lima BAV, Corrêa RS, Graminha AE, Varela Júnior JJG, da Silva ABF, Ellena J, et al. New Heteroleptic Ruii/Diphosphine Complexes With Cytotoxicity Against Human Breast and Murine Ascitic Sarcoma 180 Tumor Cells. J Braz Chem Soc (2020) 31:1352-61. doi: 10.21577/0103-5053.20200020

42. Rutkowska E, Pajak K, Jóźwiak K. Lipophilicity - Methods of Determination and its Role in Medicinal Chemistry. Acta Pol Pharm - Drug Res (2013) 70:3-18.

43. OECD. Test No. 107: Partition Coefficient (N-Octanol/Water): Shake Flask Method. OECD Guidelines for the Testing of Chemicals. (1995) 107:1-4. doi: 10.1787/9789264069626-en

44. D'Sousa CO, Araujo JH, Baliza IRS, Dias RB, Valverde F, Vidal MTA, et al. Novel Piplartine-Containing Ruthenium Complexes: Synthesis, Cell Growth Inhibition, Apoptosis Induction and ROS Production on HCT116 Cells. Oncotarget (2017) 8:104367-92. doi: 10.18632/oncotarget.22248

45. Gully CP, Velazquez-Torres G, Shin JH, Fuentes-Mattei E, Wang E, Carlock C, et al. Aurora B Kinase Phosphorylates and Instigates Degradation of P53. Proc Natl Acad Sci USA (2012) 109:1513-22. doi: 10.1073/pnas.1110287109

46. Chieffi P, Cozzolino L, Kisslinger A, Libertini S, Staibano S, Mansueto G, et al. Aurora B Expression Directly Correlates With Prostate Cancer Malignancy and Influence Prostate Cell Proliferation. Prostate (2006) 66:326-33. doi: $10.1002 /$ pros. 20345

47. Halasi M, Wang M, Chavan TS, Gaponenko V, Hay N, Gartel AL. Ros Inhibitor $N$-Acetyl-L-Cysteine Antagonizes the Activity of Proteasome Inhibitors. Biochem J (2013) 454:201-8. doi: 10.1042/BJ20130282

48. Fiorito S, Epifano F, Bruyère C, Mathieu V, Kiss R, Genovese S. Growth Inhibitory Activity for Cancer Cell Lines of Lapachol and Its Natural and Semi-Synthetic Derivatives. Bioorg Med Chem Lett (2014) 24:454-7. doi: 10.1016/j.bmcl.2013.12.049
49. Block J, Serpick A, Miller W, Wiernik P. Early Clinical Studies With Lapachol (Nsc-11905). Cancer Chemother Rep 2 (1974) 4:27.

50. Kovacic P, Somanathan R. Recent Developments in the Mechanism of Teratogenesis - Electron Transfer, Reactive Oxygen Species, and Antioxidants. Syst Biol Free Radicals Antioxid (2014) 9783642300:567-80. doi: 10.1007/978-3-642-30018-9_39

51. Barbosa MIF, Corrêa RS, De Oliveira KM, Rodrigues C, Ellena J, Nascimento OR, et al. Antiparasitic Activities of Novel Ruthenium/Lapachol Complexes. J Inorg Biochem (2014) 136:33-9. doi: 10.1016/j.jinorgbio.2014.03.009

52. Alessio E, Messori L. Anticancer Drug Candidates Face-to-Face: A Case Story in Medicinal Inorganic Chemistry. Molecules (2019) 24:1-20. doi: 10.3390/ molecules 24101995

53. Lee SY, Kim CY, Nam TG. Ruthenium Complexes as Anticancer Agents: A Brief History and Perspectives. Drug Des Devel Ther (2020) 14:5375-92. doi: 10.2147/DDDT.S275007

54. Graminha AE, Honorato J, Correa RS, Cominetti MR, Menezes ACS, Batista AA. A Novel Ruthenium(II) Gallic Acid Complex Disrupts the Actin Cytoskeleton and Inhibits Migration, Invasion and Adhesion of Triple Negative Breast Tumor Cells. Dalt Trans (2021) 50:323-35. doi: 10.1039/ dodt03490h

55. Graminha AE, Honorato J, Dulcey LL, Godoy LR, Barbosa MF, Cominetti MR, et al. Evaluation of the Biological Potential of Ruthenium(II) Complexes With Cinnamic Acid. J Inorg Biochem (2020) 206:111021. doi: 10.1016/ j.jinorgbio.2020.111021

56. Ribeiro GH, Batista AA, Guedes APM, de Oliveira TD, de Correia CRSTB, Colina-Vegas L, et al. Ruthenium(II) Phosphine/Mercapto Complexes: Their In Vitro Cytotoxicity Evaluation and Actions as Inhibitors of Topoisomerase and Proteasome Acting as Possible Triggers of Cell Death Induction. Inorg Chem (2020) 59:15004-18. doi: 10.1021/acs.inorgchem.0c01835

57. Li CJ, Li YZ, Pinto AV, Pardee AB. Potent Inhibition of Tumor Survival In Vivo by $\beta$-Lapachone Plus Taxol: Combining Drugs Imposes Different Artificial Checkpoints. Proc Natl Acad Sci USA (1999) 96:13369-74. doi: $10.1073 /$ pnas. 96.23 .13369

58. Silva EO, de Carvalho TC, Parshikov IA, dos Santos RA, Emery FS, Furtado NAJC. Cytotoxicity of Lapachol Metabolites Produced by Probiotics. Lett Appl Microbiol (2014) 59:108-14. doi: 10.1111/lam.12251

59. Marques LB, Ottoni FM, Pinto MCX, Ribeiro JM, de Sousa FS, Weinlich R, et al. Lapachol Acetylglycosylation Enhances Its Cytotoxic and Pro-Apoptotic Activities in HL60 Cells. Toxicol Vitr (2020) 65:104772. doi: 10.1016/ j.tiv.2020.104772

60. De Oliveira LG, Silva MM, De Paula FCS, Pereira-Maia EC, Donnici CL, De Simone CA, et al. Antimony(V) and Bismuth(V) Complexes of Lapachol: Synthesis, Crystal Structure and Cytotoxic Activity. Molecules (2011) 16:10314-23. doi: 10.3390/molecules 161210314

61. Sunassee SN, Veale CGL, Shunmoogam-Gounden N, Osoniyi O, Hendricks DT, Caira MR, et al. Cytotoxicity of Lapachol, $\beta$-Lapachone and Related Synthetic 1,4-Naphthoquinones Against Oesophageal Cancer Cells. Eur J Med Chem (2013) 62:98-110. doi: 10.1016/j.ejmech.2012.12.048

62. Babu MS, Mahanta S, Lakhter AJ, Hato T, Paul S, Naidu SR. Lapachol Inhibits Glycolysis in Cancer Cells by Targeting Pyruvate Kinase M2. PloS One (2018) 13:1-15. doi: 10.1371/journal.pone.0191419

63. Atolani O, Olatunji GA, Adeyemi OS. Cytotoxicity of Lapachol and Derivatized Analogues From Kigelia Africana (Lam.) Benth. on Cancer Cell Lines. Arab J Sci Eng (2020) 46:1-6. doi: 10.1007/s13369-020-05113-1

64. Mehta G, Hsiao AY, Ingram M, Luker GD, Takayama S. Opportunities and Challenges for Use of Tumor Spheroids as Models to Test Drug Delivery and Efficacy. J Control Release (2012) 164:192-204. doi: 10.1016/j.jconrel. 2012.04.045

65. Löbrich M, Jeggo PA. The Impact of a Negligent G2/M Chechpoint on Genomic Instability and Cancer Induction. Nat Rev Cancer (2007) 7:861-70. doi: $10.1038 / \mathrm{nrc} 2248$

66. Fang H, Niu K, Mo D, Zhu Y, Tan Q, Wei D, et al. Recql4-Aurora B Kinase Axis is Essential for Cellular Proliferation, Cell Cycle Progression, and Mitotic Integrity. Oncogenesis (2018) 7:68. doi: 10.1038/s41389-018-0080-4

67. Kassardjian A, Rizkallah R, Riman S, Renfro SH, Alexander KE, Hurt MM. The Transcription Factor YY1 Is a Novel Substrate for Aurora B Kinase at G2/ M Transition of the Cell Cycle. PloS One (2012) 7:23-5. doi: 10.1371/ journal.pone. 0050645 
68. Chieffi P. Aurora B: A New Promising Therapeutic Target in Cancer. Intractable Rare Dis Res (2018) 7:141-4. doi: 10.5582/irdr.2018.01018

69. Willems E, Dedobbeleer M, Digregorio M, Lombard A, Lumapat PN, Rogister B. The Functional Diversity of Aurora Kinases: A Comprehensive Review. Cell Div (2018) 13:1-17. doi: 10.1186/s13008-018-0040-6

70. Yang C, Tang X, Guo X, Niikura Y, Kitagawa K, Cui K, et al. Aurora-B Mediated Atm Serine 1403 Phosphorylation Is Required for Mitotic Atm Activation and the Spindle Checkpoint. Mol Cell (2011) 44:597-608. doi: 10.1016/j.molcel.2011.09.016

71. Zekri A, Ghaffari SH, Yaghmaie M, Estiar MA, Alimoghaddam K, Modarressi $\mathrm{MH}$, et al. Inhibitor of Aurora Kinase B Induces Differentially Cell Death and Polyploidy Via DNA Damage Response Pathways in Neurological Malignancy: Shedding New Light on the Challenge of Resistance to AZD1152-HQPA. Mol Neurobiol (2016) 53:1808-23. doi: 10.1007/s12035-015-9139-9

72. Fell VL, Walden EA, Hoffer SM, Rogers SR, Aitken AS, Salemi LM, et al. Ku70 Serine 155 Mediates Aurora B Inhibition and Activation of the DNA Damage Response. Sci Rep (2016) 6:1-17. doi: 10.1038/srep37194

73. Martin A, Byrne A, Burke CS, Forster RJ, Keyes TE. Peptide-Bridged Dinuclear Ru (II) Complex for Mitochondrial Targeted Monitoring of Dynamic Changes to Oxygen Concentration and ROS Generation in Live Mammalian Cells. J Am Chem Soc (2014) 136:15300-9. doi: 10.1021/ja508043q

74. Costa MS, Gonçalves YG, Borges BC, Silva MJB, Amstalden MK, Costa TR, et al. Ruthenium (II) Complex Cis-[Ruii $\left.\left(\mathrm{N}_{2}-\mathrm{O}_{2} \mathrm{Cc}_{7} \mathrm{~h}_{7} \mathrm{O}_{2}\right)(\mathrm{Dppm}) 2\right] \mathrm{Pf}_{6^{-}}$ Hmxbato Induces ROS-Mediated Apoptosis in Lung Tumor Cells Producing Selective Cytotoxicity. Sci Rep (2020) 10:1-21. doi: 10.1038/ s41598-020-72420-w

75. Schieber M, Chandel NS. ROS Function in Redox Signaling. Curr Biol (2014) 24:453-62. doi: 10.1016/j.cub.2014.03.034.ROS

76. Kruiswijk F, Labuschagne CF, Vousden KH. p53 in Survival, Death and Metabolic Health: A Lifeguard With a Licence to Kill. Nat Rev Mol Cell Biol (2015) 16:393-405. doi: 10.1038/nrm4007

77. Lima AP, Pereira FC, Almeida MAP, Mello FMS, Pires WC, Pinto TM, et al. Cytoxicity and Apoptotic Mechanism of Ruthenium(II) Amino Acid Complexes in Sarcoma-180 Tumor Cells. PloS One (2014) 9(10):e105865. doi: 10.1371/journal.pone.0105865

78. Nakahara T, Takeuchi M, Kinoyama I, Minematsu T, Shirasuna K, Matsuhisa A, et al. YM155, A Novel Small-Molecule Survivin Suppressant, Induces Regression of Established Human Hormone-Refractory Prostate Tumor Xenografts. Cancer Res (2017) 67:8014-21. doi: 10.1158/0008-5472.CAN-07-1343

79. Hurtado M, Sankpal UT, Kaba A, Mahammad S, Chhabra J, Brown DT, et al. Novel Survivin Inhibitor for Suppressing Pancreatic Cancer Cells Growth Via Downregulating Sp1 and Sp3 Transcription Factors. Cell Physiol Biochem (2018) 51:1894-907. doi: 10.1159/000495715

80. Schettini F, De Santo I, Rea CG, De Placido P, Formisano L, Giuliano M, et al. Cdk 4/6 Inhibitors as Single Agent in Advanced Solid Tumors. Front Oncol (2018) 8:608. doi: 10.3389/fonc.2018.00608
81. Sheppard KE, McArthur GA. The Cell-Cycle Regulator CDK4: An Emerging Therapeutic Target in Melanoma. Clin Cancer Res (2013) 19:5320-8. doi: 10.1158/1078-0432.CCR-13-0259

82. Tang D, Wu D, Hirao A, Lahti JM, Liu L, Mazza B, et al. Erk Activation Mediates Cell Cycle Arrest and Apoptosis After DNA Damage Independently of P53. J Biol Chem (2002) 277:12710-7. doi: 10.1074/jbc.M111598200

83. Lee ECY, Frolov A, Li R, Ayala G, Greenberg NM. Targeting Aurora Kinases for the Treatment of Prostate Cancer. Cancer Res (2006) 66:4996-5002. doi: 10.1158/0008-5472.CAN-05-2796

84. Yi Q, Chen Q, Yan H, Zhang M, Liang C, Xiang X, et al. Aurora B Kinase Activity- Dependent and -Independent Functions of the Chromosomal Passenger Complex in Regulating Sister Chromatid Cohesion. J Biol Chem (2019) 294:2021-35. doi: 10.1074/jbc.RA118.005978

85. Addepalli MK, Ray KB, Kumar B, Ramnath RL, Rao H. Rnai-Mediated Knockdown of AURKB and EGFR Shows Enhanced Therapeutic Efficacy in Prostate Tumor Regression. Gene Ther (2009) 17:352-9. doi: 10.1038/ gt.2009.155

86. Pan HW, Su HH, Hsu CW, Huang GJ, Wu TTL. Targeted TPX2 Increases Chromosome Missegregation and Suppresses Tumor Cell Growth in Human Prostate Cancer. Onco Targets Ther (2017) 10:3531-43. doi: 10.2147/ OTT.S136491

87. Zekria A, Mesbahi Y, Ghanizadeh-Vesali S, Alimoghaddam K, Ghavamzadeh A, Ghaffari SH. Reactive Oxygen Species Generation and Increase in Mitochondrial Copy Number: New Insight Into the Potential Mechanism of Cytotoxicity Induced by Aurora Kinase Inhibitor, Azd1152-Hqpa. Anticancer Drugs (2017) 28:841-51. doi: 10.1097/CAD.0000000000000523

88. Jessen C, Kreß JKC, Baluapuri A, Hufnagel A, Schmitz W, Kneitz S, et al. The Transcription Factor NRF2 Enhances Melanoma Malignancy by Blocking Differentiation and Inducing Cox2 Expression. Oncogene (2020) 39:6841-55. doi: 10.1038/s41388-020-01477-8

89. Mancini F, Pieroni L, Monteleone V, Lucà R, Fici L, Luca E, et al. Mdm4/ Hipk2/P53 Cytoplasmic Assembly Uncovers Coordinated Repression of Molecules With Anti-Apoptotic Activity During Early DNA Damage Response. Oncogene (2016) 35:228-40. doi: 10.1038/onc.2015.76

Conflict of Interest: The authors declare that the research was conducted in the absence of any commercial or financial relationships that could be construed as a potential conflict of interest.

Copyright (c) 2021 De Grandis, Oliveira, Guedes, dos Santos, Aissa, Batista and Pavan. This is an open-access article distributed under the terms of the Creative Commons Attribution License (CC BY). The use, distribution or reproduction in other forums is permitted, provided the original author(s) and the copyright owner(s) are credited and that the original publication in this journal is cited, in accordance with accepted academic practice. No use, distribution or reproduction is permitted which does not comply with these terms. 